

\section{Campiñas de Jerez y Medina: vino, caballos y toros entre dos mares}

Esta sección ha sido elaborada, además de los firmantes, gracias a la colaboración de Silvia Fernández Cacho, Valle Muñoz Cruz, Aniceto Delgado Méndez, Ma Victoria Madrid Díaz, Isabel Guzmán Guzmán, Luisa Fernanda de Juan Santos, Carmen Pizarro y Salud Soro Cañas
La fisonomía de las campiñas de Jerez de la Frontera y Medina Sidonia queda definida por el marcado contraste que existe entre los otros paisajes que las delimitan y que completan la unidad medioambiental de la provincia de Cádiz: la sierra y la costa. La hegemonía de la actividad económica y social vinculada a los cultivos vitivinicolas y a la ganadería vacuna traza el perfil físico de una comarca que queda jalonada por un patrimonio arquitectónico, urbano y rural, en el que predominan casas de viña, cortijos, haciendas, bodegas, plazas de toros y tentaderos. Escenario de muchos de los más importantes hitos históricos de Andalucia desde la Antigüedad, este paisaje también atesora un importante y múltiple patrimonio arqueológico, monumental y cultural, un espacio que ofrece nuevas perspectivas paisajisticas gracias a la autovía Jerez-Los Barrios, auténtica columna vertebral de la comarca, y eje comercial e industrial que une sus dos ciudades principales. 


\section{Campiñas de Jerez y Medina}

José Manuel Aladro Prieto, Dpto. de Historia, Teoría y Composición

Arquitectónicas, Universidad de Sevilla
Pocos territorios soportan como éste tan arraigados y extendidos tópicos, y en no más ocasiones estos lugares comunes están tan fuertemente enraizados en el territorio, responden en gran medida a su auténtica esencia cultural y patrimonial, y son asumidos y reconocidos como símbolos del propio territorio. Toros, vino, caballos o flamenco constituyen algunos de los símbolos-tópicos de la campiña gaditana, y aunque no son desde luego exclusivos de esta provincia ni de la comarca, en ésta adquieren una intensidad extraordinaria. Son símbolos que remiten a un pasado mítico y literario, y que al mismo tiempo encarnan importantes facetas del presente, de ahi su vigencia y potencia. Su fuerza extraordinaria como emblema ha permitido que algunos de ellos trasciendan las propias fronteras comarcales alcanzando rango de símbolo nacional. El manido pero eficiente ejemplo del Toro de Osborne o el indultado Tío Pepe de la Puerta del Sol madrileña son buena prueba de ello. Paralelamente, la indiscutible potencia de estos tópicos, y el esplendor actual o histórico de las realidades que traslucen, han dificultado la lectura real de la riqueza y pluralidad de la comarca, cuya amplitud cultural, agrícola o paisajistica, va más allá de los mismos. Riqueza que tiene su concreción en una variada y compleja densidad patrimonial que abarca desde la potencia documental del Archivo Ducal de Medina Sidonia al amplio y atractivo conjunto de Poblados de Colonización construidos en el siglo XX.

En una provincia plural, de unidades medioambientales dificilmente fraccionables, las campiñas de Jerez y Medina se definen en oposición a las unidades que la delimitan dentro de la provincia de Cádiz: la costa y la sierra. La Campiña es el sector central de la mitad norte de la provincia, delimitado al Oeste y Sur por las comarcas costeras de la Bahía de Cádiz, Estrecho y Campo de Gibraltar y al Este por las, a veces, imponentes pendientes de la serranía de Cádiz-Ronda. Comarca heterogénea agrícola y paisajisticamente, comprende parcial o totalmente tres grandes municipios centrales: Jerez de la Frontera, Medina Sidonia y Arcos de la Frontera, y una constelación de municipios menores ubicados en la periferia de los anteriores a caballo entre las unidades mediambientales costeras y serranas: Sanlúcar de Barrameda, Chipiona, Rota, El Puerto de
Santa María, Puerto Real, Benalup-Casas Viejas, Paterna de Rivera, San José del Valle, Espera, Bornos y Villamartín. Surcadas por los cursos medios de los ríos Guadalete y Barbate, con amplios valles para la agricultura y escasa altitud, su aprovechamiento natural es básicamente agrario con grandes explotaciones de secano. En este territorio fuertemente antropizado se adentran en contraste las estribaciones del Parque Natural de Los Alcornocales y surge la reserva hídrica y ornitológica de la Laguna de Medina, felizmente rescatada de su degradación no hace muchos años.

La tradicional preponderancia económica y social del cultivo de la vid, presente en un reducido sector del noroeste de la campiña, ha minimizado el predominio histórico y actual del cereal, la importancia, incrementada en las últimas décadas, de la ganadería vacuna, de engorde y brava, o los restos del olivar, de cuya relevancia histórica hasta mediados del XVIII quedan vestigios en los municipios más al NE de la campiña. El viento de levante, quizá el más relevante agente atmosférico de la comarca, ha condicionado la práctica agrícola en la mitad sur campiñesa, término de Medina, favoreciendo la implantación de la ganadería vacuna en amplias extensiones del territorio.

Los aprovechamientos agricolas y ganaderos tradicionales han generado un importante patrimonio edificado urbano y rural. Los paisajes protagonizados por la ganadería brava o la vid tienen su referente urbano en un estimable conjunto de plazas de toros, y en un incomparable patrimonio bodeguero ubicado principalmente en las tres ciudades del Marco del Jerez: Sanlúcar, El Puerto y Jerez. En el ámbito rural, cortijos, haciendas y casas de viñas permanecen como testigos construidos de la condición agraria de la comarca y de su peso histórico, conformando un conjunto cultural y etnográfico de incalculable magnitud patrimonial.

Como sede de la mítica Tartessos, como primera provincia de AlAndalus tras la conquista de Medina Sidonia, o como punta de lanza de la modernización decimonónica, la comarca campiñesa ha sido históricamente soporte, en ocasiones protagonista, de la práctica totalidad de las secuencias históricas que han configurado la perso- 


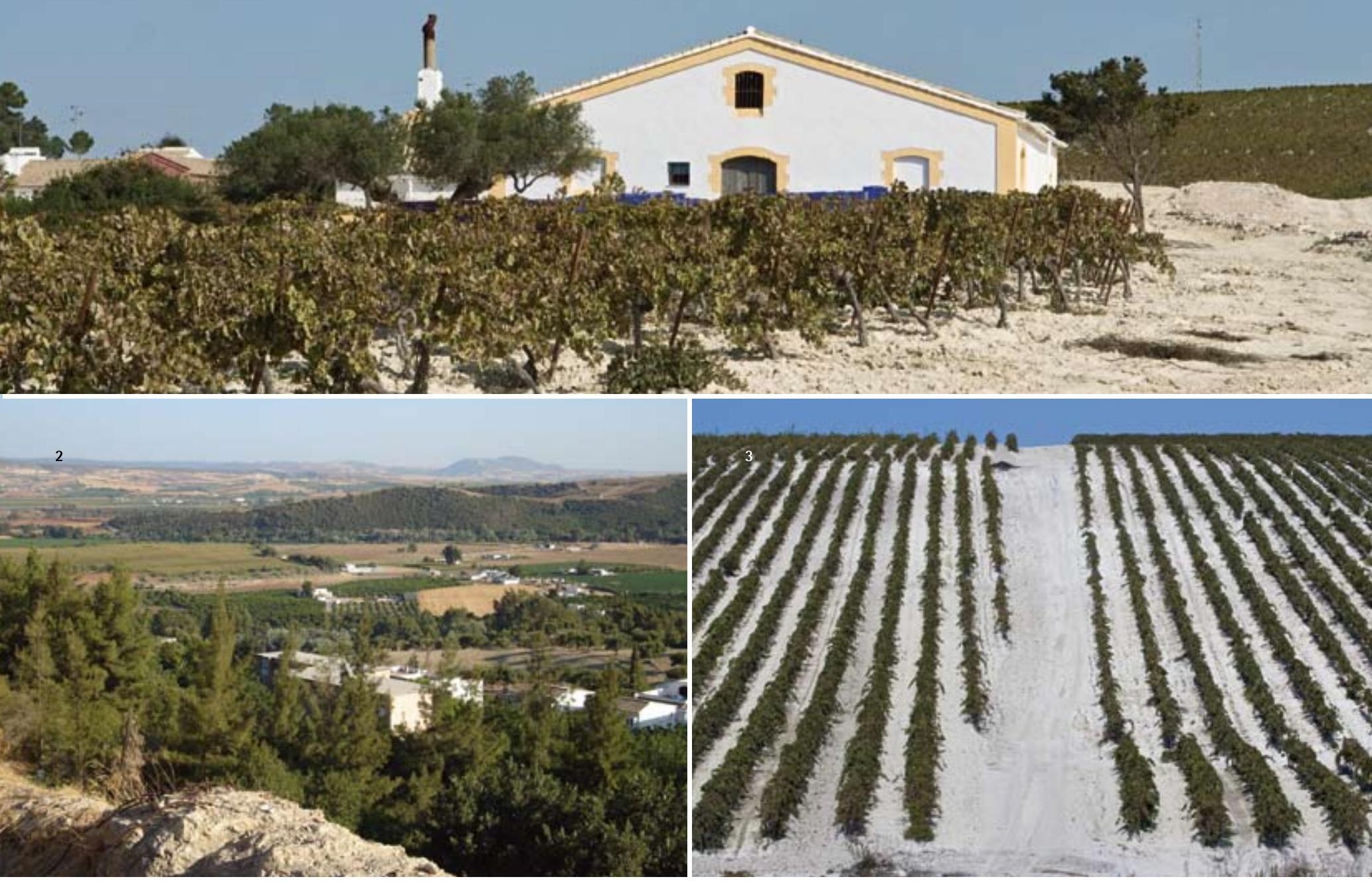

Las últimas décadas han supuesto un revulsivo histórico en las comunicaciones e infraestructuras de la provincia, con una amplia incidencia en la campiña central

1 y 3. La edilicia y el cultivo vitícola constituyen elementos emblemáticos de la campiña, reconocidos como tales a pesar de su localizada implantación territorial. Foto: Juan Carlos Cazalla, IAPH

2. El paisaje rural de Medina Sidonia es notablemente diferente al de Jerez, sin llegar a ser serrano. Foto: Simon Kay

4. Los tabancos, donde se degusta el vino y el mosto de la tierra, son recintos consagrados a la convivencia social. Tabanco El Pasaje, Jerez de la Frontera. Foto: Juan Carlos Cazalla, IAPH

5. La tradicional actividad agrícola y ganadera ha generado un patrimonio inmueble con un grado de uso y preservación superior al de otros territorios. Foto: Rodolfo Infantino

6. El sector ganadero vacuno, bravo y de engorde, ha incrementado su importancia en esta comarca en las últimas décadas. Foto: Juan Carlos Cazalla $\mathrm{APH}$

7. Las casas de viña han configurado un singular modelo arquitectónico específico del Marco del Jerez. Foto: Juan Carlos Cazalla, IAPH

8. La actividad de la ganadería brava propicia la construcción de numerosas plazas de toros y tentaderos rurales. Foto: Juan Carlos Cazalla, IAPH nalidad cultural andaluza. Tan denso devenir histórico ha dotado a la comarca de una compleja y multifacética realidad patrimonial arqueológica, monumental y cultural. El importante conjunto de yacimientos arqueológicos; Doña Blanca (El Puerto), Asta Regia (Jerez) o Carissa (Bornos), permite establecer lecturas sincrónicas superpuestas del territorio comarcal. Los conjuntos monumentales urbanos, Jerez, Medina o Arcos, conviven con piezas rurales de extraordinaria valía como la Cartuja de Santa Maria de la Defensión. Mientras, la ancestral sintesis cultural pervive aún en ritos y costumbres con ejemplos de elevado y provechoso reconocimiento, caso de la reposteria de origen mudéjar de Medina Sidonia.

Las últimas décadas han supuesto un revulsivo histórico en las comunicaciones e infraestructuras de la provincia, con una amplia incidencia en la campiña central. La esperada y dilatada Autovía Jerez-Los Barrios constituye una extraordinaria columna vertebral para toda la comarca, que fortalece por fin el eje comercial e industrial entre los dos principales polos económicos de la provincia. Como la anterior, la nueva variante de la N-IV a su paso por Jerez ha abierto nuevas perspectivas paisajisticas sobre el territorio comarcal descubriendo vistas inusitadas de la ciudad y desvelando, por primera vez hacia una vía de gran tráfico, el sector central del paisaje histórico del viñedo. 

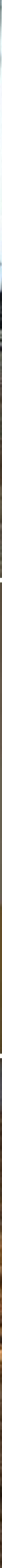


\section{El archivo de la Fundación Casa de Medina Sidonia: un sueño hecho realidad}

La Fundación Casa de Medina Sidonia es una institución creada en el año 1990 por doña Luisa Isabel Álvarez de Toledo, XXI Duquesa de Medina Sidonia. Ya con anterioridad el Palacio, con todo cuanto contiene, fue declarado Monumento Histórico Artístico Nacional. Su objetivo principal es la conservación y difusión de los bienes que lo integran: el archivo histórico de los Duques de Medina Sidonia, compuesto por más de seis millones de documentos; el Palacio de Sanlúcar de Barrameda, que data del siglo XII, y su patrimonio pictórico y mobiliario. En este principio de valorización del patrimonio cultural, la Fundación organiza conferencias, seminarios, exposiciones, cursos de verano -durante varios años acogió a la Universidad Nacional de Educación a Distancia en sus instalaciones-, conciertos, y divulga, a través del estudio de sus fondos documentales, por parte de los investigadores que acuden al archivo, los trabajos de historia que éstos realizan.

Quiso la fundadora, y así queda reflejado en los estatutos fundacionales, que esta institución fuese centro difusor de cultura, debiendo servir al hombre en su búsqueda de la verdad objetiva, que tiene por base el conocimiento del pasado; pues las sociedades, como bien queda señalado en nuestro Ideario, "no pueden asumir lo nuevo, partiendo del vacío".

Podemos afirmar, sin lugar a equivocarnos, que la importancia de este archivo radica en la composición de sus fondos documentales, constituidos por seis millones de documentos, reunidos en 6245 legajos, 0 unidades de instalación, lo que nos permite profundizar desde diversos ángulos: económicos, políticos, filosóficos, sociológicos, juridicos, etcétera, en periodos que nos ofrecen la imagen del mundo tal y como fue, distinguiendo el "gran hecho" del minúsculo, dándonos a conocer los fundamentos inherentes que tienen las acciones de los hombres en la construcción y devenir de las sociedades.

En este archivo se reúne la documentación que distintas familias, o casas, fueron generando a lo largo de los siglos, siendo el bloque documental más grande el de Medina Sidonia, que data de finales del siglo XIII (1297). Está el archivo de los Vélez (Fajardo), el de Requesens (Martorell), Montalto (Aragón y Moncada), Maza de Linaza (Caro y Romana) y el de Villafranca (de Toledo), este último menos completo que el de Medina Sidonia, pero es el que nos ofrece la documentación más antigua, que comienza en el año 1190.

La ordenación por materias es prácticamente la misma para todas las casas, quedando reflejada en los siguientes bloques temáticos, construidos a partir de los catálogos realizados por la fundadora, y que obran en el Archivo, siendo la herramienta principal de trabajo para el investigador a la hora de realizar la búsqueda documental:

\section{Sección Privada:}

a) Nacimientos, matrimonios, testamentos y testamentarías, con un apartado de pleitos que dimanan de ello, como por ejemplo: separaciones y sucesiones. b) Correspondencia de carácter familiar o social. Correspondencia privada, que nos señala fundamentalmente la construcción social y mental de la sociedad del momento.

c) Cuentas particulares, en las que queda reflejado el gasto personal, como pueden ser los salarios de criados, sastres, adquisición de bienes, usos alimenticios, gustos, etcétera. Sueldos de pintores, escultores, armeros, plateros, joyeros, entre otros oficios o profesiones.

d) Deudas, censos, juros y pleitos tocantes a estos temas, que nos hablan a su vez del mundo de la justicia y de las estrategias de poder que construyen las sociedades, describiéndonos la función activa que ejercen las partes en litigio. En la misma sección, pero en apartado distinto nos encontramos las instrucciones a los administradores, tesoreros y secretarios, asi como los mecanismos utilizados por los bancos $y$ banqueros a la hora de adelantar o facilitar el tránsito del dinero que prestan.

e) Rentas jurisdiccionales o señoriales; bienes propios unidos al mayorazgo, bienes libres. Apartado que queda subdividido por la documentación que nos remite a las formas de arriendo de las dehesas, huertas, viñas, casas, molinos, mesones, y demás propiedades de las distintas casas.

f) Encomiendas, que solia dar el rey a las casas que estaban en apuros financieros, así como los ingresos dimanantes de privilegios reales y rentas vitalicias. En este apartado también debemos incluir los ingresos que dimanaban del ejercicio de los distintos cargos que ejercian los nobles; ingresos que nunca llegaron a cubrir los gastos del empleo. Se trata de empleos políticos o militares, como los virreinatos, capitanías generales, etcétera, o los honorificos, como los hábitos de órdenes, condecoraciones y otros, sin carácter lucrativo, o con pensiones mínimas.

g) Patronatos generales de órdenes, provinciales o locales. Fundaciones de conventos o iglesias: bulas, buletos, excomuniones, censura y pleitos eclesiásticos.

h) Obras sociales, documentación que nos remite a la creación o fundación de hospitales, colegios, asilos, limosnas y situados vitalicios.

\section{Sección Estado o Señorío:}

a) Impuestos o tributos con cargo a los pueblos del estado, bien por pertenecer a señorí, o bien por haberlos adquirido por compra, como los llamados alcabalas, terrazgo, almotacén, aduana, etcétera. Ingresos dimanantes del alquiler sobre las tiendas públicas, carniceria, pescaderías, casas de mujeres, hornos y molinos.

b) Privilegios y concesiones a los pueblos en su conjunto, a vecinos en particular, a nuevos pobladores.

c) Órdenes tocantes a cuestiones de gobierno y administración pública. Intervención en demandas contra los justicias y entre los vecinos (Tribunal de Apelación o Consejo).

d) Obras públicas; introducción de industrias, repoblaciones forestales e introducción de plantas y técnicas agrarias.

e) Elecciones de justicias; pleitos con el vecindario, generalmente sobre propiedad de tierras, cobro de impuestos o legítima del señorío jurisdiccional.

f) Pleitos con los vasallos, generalmente por deudas o desacato. A veces contra un grupo, otros contra un particular. Correspondencia con justicias y vecinos.

g) Relación con la corona: privilegios reales, concediendo el señorío. Pleitos de la corona contra las regalias del señor (recuperación de impuestos, tierras y otros, dados por anteriores soberanos).

h) Relaciones entre el rey y los pueblos: privilegios reales, fueros, concesión de dehesas, etcétera. Pleitos de los pueblos contra la corona: recuperación de tierras, en torno a impuestos, que son de la ciudad o lugares. Contra los oficiales de la corona.

j) Relaciones entre los pueblos: privilegios, pleitos de la villa en torno a su jurisdicción. Pleitos con lugares vecinos sobre comunidad de pastos, entradas de ganado, límites, apeos, deslindes. Pleitos entre los vecinos, causas criminales, delitos, acuerdos y desacuerdos del cabildo. Elecciones de justicias, juicios de residencias.

k) Urbanismo y obras públicas; fiestas populares, servicios sociales; médicos, maestros; escribanías y procuradores. Oficios públicos en general. Informes y descripciones geográficas, económicas e históricas de los lugares. Baldios y su administración, dehesas y su administración. Bienes privados.

Esta rica documentación nos permite estudiar y entender el pasado en todos sus aspectos, mostrándonos con su lenguaje propio nuestro devenir como hombres, pues el saber de dónde venimos nos ayuda a comprender lo que hoy somos y representamos. Asi lo han podido comprobar los cientos de investigadores y estudiosos que han pasado por su sala, estudiando sus ricos fondos documentales; dando vida a innumerables trabajos históricos que han enriquecido el panorama científico de nuestro país.

Para finalizar quisiera aprovechar estas páginas para recordar a las instituciones públicas que son los garantes de que este patrimonio se conserve y se difunda, para ello hace falta que colaboren activamente en la consecución de los fines fundacionales, tal y como dispuso doña Luisa Isabel Álvarez de Toledo al constituir la Fundación. En esta nueva andadura, los patronos hemos de ser conscientes de que es necesario dar una mayor difusión a las actividades que se realizan en torno al Archivo, que ha de ser considerado Patrimonio Mundial, por ello es preciso que dispongamos de los recursos necesarios, tanto técnicos como económicos, para llevar a cabo esta ingente tarea que nos fue confiada en toda su complejidad y diversidad, y a la que debemos dar la mayor difusión posible.

Liliane $M^{a}$ Dahlmann

Presidenta de la Fundación Casa de Medina Sidonia 


\section{La autovía A-381 en el paisaje de las campiñas de Cádiz}

Ignacio Español Echaniz y David de Santos Marián, Ingenieros de

Caminos, Canales y Puertos

La percepción que las poblaciones tienen del territorio, es decir, su paisaje, tiene que ver con las actividades que desarrollan en él. La manera de moverse sobre el territorio explica el modo que se tiene de entenderlo y apreciarlo.

Ya de antiguo el paisaje de las campiñas de Jerez de la Frontera y de Medina Sidonia ha sido el característico de un territorio de agricultura extensiva organizado mediante una jerarquía de núcleos de población centrales que se completa con el salpicado regular y disperso de poblados y cortijos, centro residencial de las grandes explotaciones agrarias. Esta organización polinuclear y regular de las campiñas resultó eficaz con los sucesivos cambios de orientación de las fronteras y también luego cuando sirvió a una organización ordenada de la explotación de los recursos agrarios.

La tupida red de caminos existentes entre los pueblos, los poblados y los cortijos vendría a explicar muy bien la relación que la población ha tenido con su paisaje a lo largo de su historia. Ya desde la época de los romanos existían calzadas que cruzaban la campiña y la relacionaban tanto con la costa, con Cádiz, como con el interior (Sevilla). La conquista por parte de los cristianos de las comarcas fronterizas al reino nazari de Granada debió consolidar el eje interior frente a los caminos litorales que desde Cádiz permitían llegar a Algeciras.

Luego, la progresiva construcción de un estado peninsular se tradujo en la consolidación de este eje por el oeste de la campiña de Jerez apoyado en los itinerarios de postas y en los caminos de ruedas y de herradura hasta bien entrado el siglo XVIII.

La industrialización transformó el paisaje de la campiña de Jerez introduciendo la viña y las bodegas del ámbito prelitoral de la Bahía de Cádiz y trajo, en 1853, la linea de Jerez al muelle del Trocadero, en Puerto Real, el primer ferrocarril de Andalucia y uno de los primeros de España. El ferrocarril introdujo una mayor capacidad de viaje: grandes volúmenes de personas y productos podian ser transportados con velocidad por el territorio. Con ello trajo también una nueva relación del viajero con el paisaje, ahora más apresurado y más distante aún que antes, también más visual e intelectualizado.

La modernización en el siglo XIX y el primer tercio del siglo XX introdujo primero la red de caminos carreteros y luego las carreteras con firmes manteniendo el itinerario del oeste de la campiña de Jerez, con la N-IV, y el de la costa, con la N-340. Se incrementó así la velocidad y calidad del viaje, también su capacidad. La segunda mitad del siglo XX asistió a una profunda revolución social. La motorización y el desarrollo de la industria en las dos bahías gaditanas hicieron perder peso a la agricultura, fomentando el crecimiento de las ciudades medias en detrimento de la red de asentamientos más rural y disperso.

El aumento de la velocidad que permitieron los nuevos vehículos y carreteras provocó un cierto distanciamiento del medio que se cruzaba. Se empezó a ver el campo como un lugar diferente y especial, un tanto ajeno a la vida cotidiana y por eso dotado de una identidad singular, primero vista como materialización del atraso y, más tarde, atractiva por su calidad ambiental y paisajistica.

Al inicio de los setenta la construcción de la autopista de SeviIla a Cádiz traía un modelo de infraestructura de alta capacidad que anticipaba la manera actual de entender el territorio y de apreciar su paisaje. La autopista con calzadas separadas y capacidad para un elevado nivel de tráfico conectaba el entorno de Sevilla con el entorno de Puerto Real pasando junto a Jerez con un trazado diseñado para una velocidad elevada. Aislada de sus márgenes por un cerramiento continuo sólo se permite su acceso en unos pocos enlaces, de modo que socialmente tiene una naturaleza "aérea" pues sólo sirve a los extremos y en los enlaces y selectivamente debido al peaje. Por el contrario, tiene una notable presencia física por su anchura y por la velocidad a la que sirve, que le obliga a suavizar las formas del terreno natural generando excavaciones y terraplenes.

La relación del viajero con el paisaje en esta vía es claramente cinematográfica, pues se tiene la sensación de desplazarse frente 

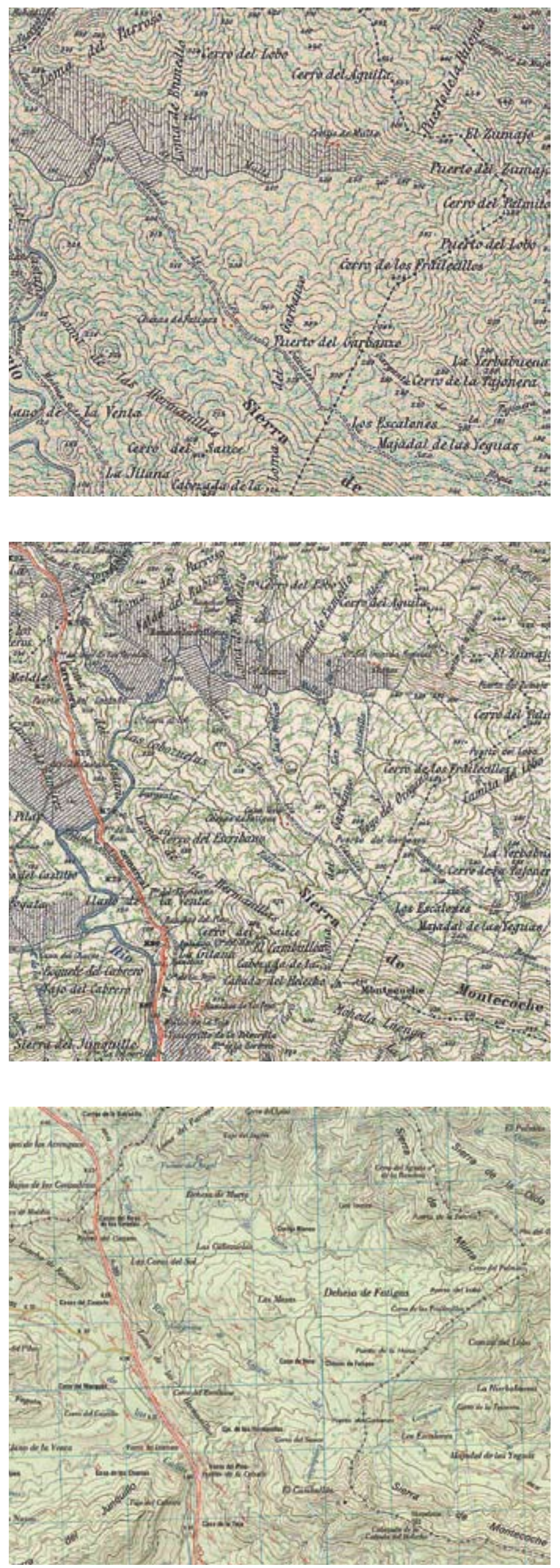

Camino de Alcalá de los Gazules, 1918 (arriba), carretera comarcal, 1960 (centro) y trazado de la Autovía A-381, 2005 (abajo). Los distintos trazados presentan a diferentes lecturas culturales del paisaje. Fuente: Instituto Geográfico Nacional a una serie de imágenes, de paisajes visuales, que se desplazan a sus lados. Además, sus márgenes cierran las vistas a menudo con un denso arbolado de porte dirigiendo la mirada al propio paisaje interior de sus calzadas.

Esta autopista se construyó con un gran esfuerzo tecnológico e innovador para su época, presentándose como un icono de modernidad y progreso que ponía a la región y al pais a la altura de Europa. Asumió así una función simbólica que ya en este milenio se haría común entre las grandes obras públicas al punto de desplazar en importancia social e ideológica a la propia necesidad de su servicio. Su aparición en los años setenta coincide con el inicio del desarrollo de los medios de comunicación visuales que han ganado tanto protagonismo en las actuales actitudes colectivas, colaborando con la simplificación de la idea del paisaje a una mera escena visual.

La autopista de Sevilla-Cádiz sirve a desplazamientos de largo recorrido, en el corredor de la carretera N-IV, desdoblada en autovia finalmente en 1993. La red de carreteras que recorren las campiñas se fue mejorando sirviendo tanto a desplazamientos comarcales como a la centralidad local de sus núcleos urbanos. Éstos, aunque debilitados por la competencia de las grandes ciudades centrales de la costa y Jerez, y por el creciente desarrollo del turismo de playa, han seguido manteniéndose como enclaves de referencia social. La carretera N-340, una actualización del antiguo itinerario litoral y hoy día desdoblada en autovía en casi todo su recorrido, asumió el servicio de conexión intraprovincial que habria de servir a las relaciones entre las áreas más dinámicas de las dos bahías.

El final del siglo XX ha visto la absoluta generalización del vehículo privado que ha pasado a ser un elemento imprescindible de la vida cotidiana también en las campiñas. La distancia media recorrida fue ampliándose gracias a la mejora de la red y de los vehículos, liberando la estructura tradicional de las áreas urbanas. Esto, unido a un modelo liberal de gestión de los usos del suelo, ha dado paso a un modelo urbano expandido que supera el espacio de la ciudad tradicional extendiéndose como una malla por territorios muy extensos. La jornada diaria de un ciudadano medio puede ahora transcurrir en varias localizaciones distantes entre sí en más de 100 kilómetros. Este modo de vida viene sostenido por un territorio que se ha sintetizado a lo reticular y a sus nodos (núcleos urbanos, nuevos centros comerciales), construido sobre las carreteras y que abandona los amplios espacios intersticiales que quedan entre medio. Éstos se perciben como espacios vacios que son vistos en la distancia desde la red, a la velocidad que reclama la apretada organización del tiempo, como postales de paisajes pintorescos.

En este contexto surge la autovía A-381 de Jerez de La Frontera a Los Barrios, un eje dotado de las capacidades de una vía de altas prestaciones, para la conexión entre dos de los grandes conjuntos urbanos de Cádiz. 
Su aparición en la campiña recuerda en muchos aspectos a la de su antecesora la autopista de peaje Sevilla-Cádiz. La nueva autovía sirve a los desplazamientos entre las áreas más dinámicas de la provincia y gracias a sus numerosos enlaces atiende también a los accesos a los núcleos de la campiña de Medina-Sidonia. Esencialmente es una vía para el reciente modelo urbano expandido, que pone en conexión rápida el empleo, los servicios y las residencias de sus extremos y de la campiña. También prolonga la capacidad de las vías de altas prestaciones conectándose con la AP-4 en Jerez y la A-7 en Algeciras. De esta manera todos los espacios de actividad están ahora más cerca entre sí.

Para proporcionar este servicio de gran velocidad y capacidad, la infraestructura arranca al sur de Jerez y se desliza con grandes curvas por las Ilanuras de regadio, evita la Laguna de Medina, discurre entre Paterna y Medina Sidonia, pasa al sur de Alcalá de Los Gazules y recorta las colas del embalse del río Barbate para adentrarse en el terreno más abrupto del Parque Natural de Los Alcornocales. Cruza sobre la cola del embalse del río Palmones y continúa junto a los meandros del río para acceder finalmente a Los Barrios en el área metropolitana de Algeciras. El trazado de la carretera que antes hacia este servicio se ha mantenido en gran parte de su trazado serpenteando con el tronco de la autovia de manera que la presencia del conjunto de vías es notoria en esos tramos.

Como en el caso de la AP-4 Sevilla-Cádiz, la construcción de esta autovía, una costosa iniciativa asumida por la administración autonómica, ha asumido su función icónica con una fuerte carga de innovación y modernidad que se refiere ahora a un nuevo tipo de progreso que combina servicio y funcionalidad con la necesidad de una adecuada integración paisajística. Técnicamente, la obra despliega elementos de integración a su paso por el Parque Natural de Los Alcornocales como pasos de fauna, restitución de vías pecuarias o miradores del paisaje. A través de procedimientos administrativos especificos e interactivos, durante las tres últimas décadas se ha venido exigiendo a los proyectos de carreteras reducir sus efectos negativos sobre los procesos del territorio, especialmente si se tratan de las valiosas y singulares estructuras de la naturaleza que presentan estas sierras de alcornocales y otros bosques mediterráneos. Es así que la iniciativa de construir una vía de alta capacidad a través de un paisaje especialmente sensible se realiza acompañada de ajustes locales y dispositivos de integración.

A diferencia de la AP-4, la autovía Jerez-Los Barrios sirve a desplazamientos cotidianos de carácter provincial, en realidad de la nueva organización territorial de lo urbano, y en ese sentido, materializa muy bien las aspiraciones de la sociedad contemporánea y su relación con el paisaje real.

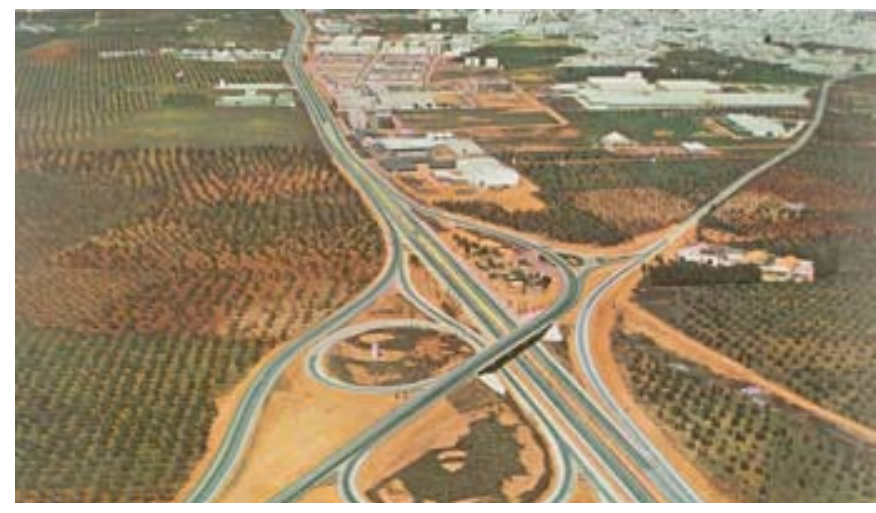

La autopista de Sevilla a Cádiz, un diseño de gran capacidad, hoy superado. Fuente: Bética de Autopistas, S.A. Memoria 1972

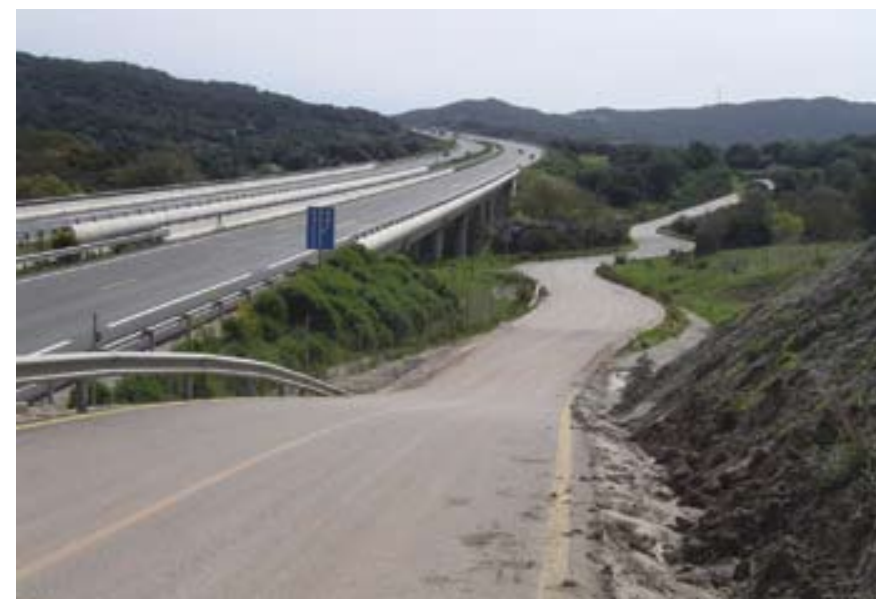

El trazado aéreo de la Autovía A-381 presenta una visión superficial del paisaje. Fuente: Centro de Estudios Paisaje y Territorio (CEPT)

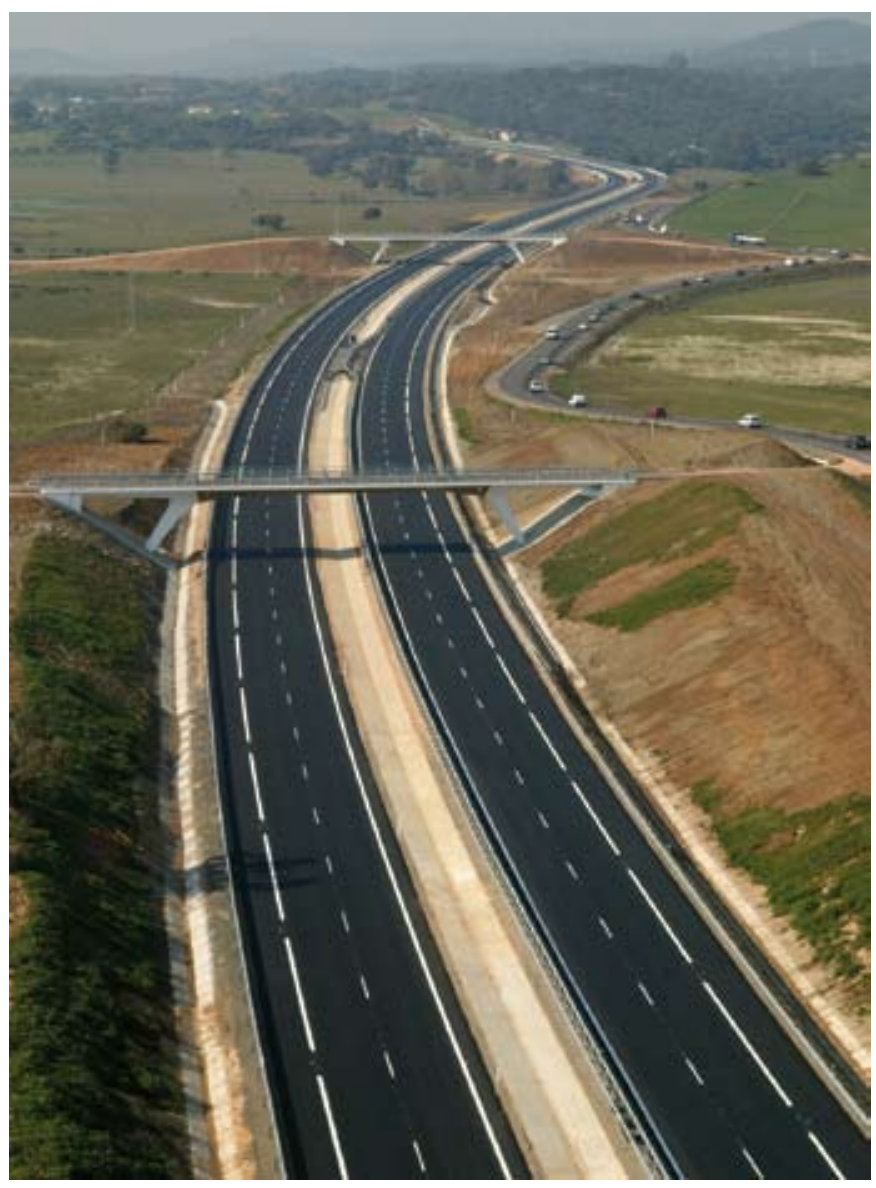

La autovía A-381 entre Jerez y Los Barrios combina servicio y funcionalidad con una adecuada integración paisajística. Fuente: Centro de Estudios Paisaje y Territorio (CEPT) 


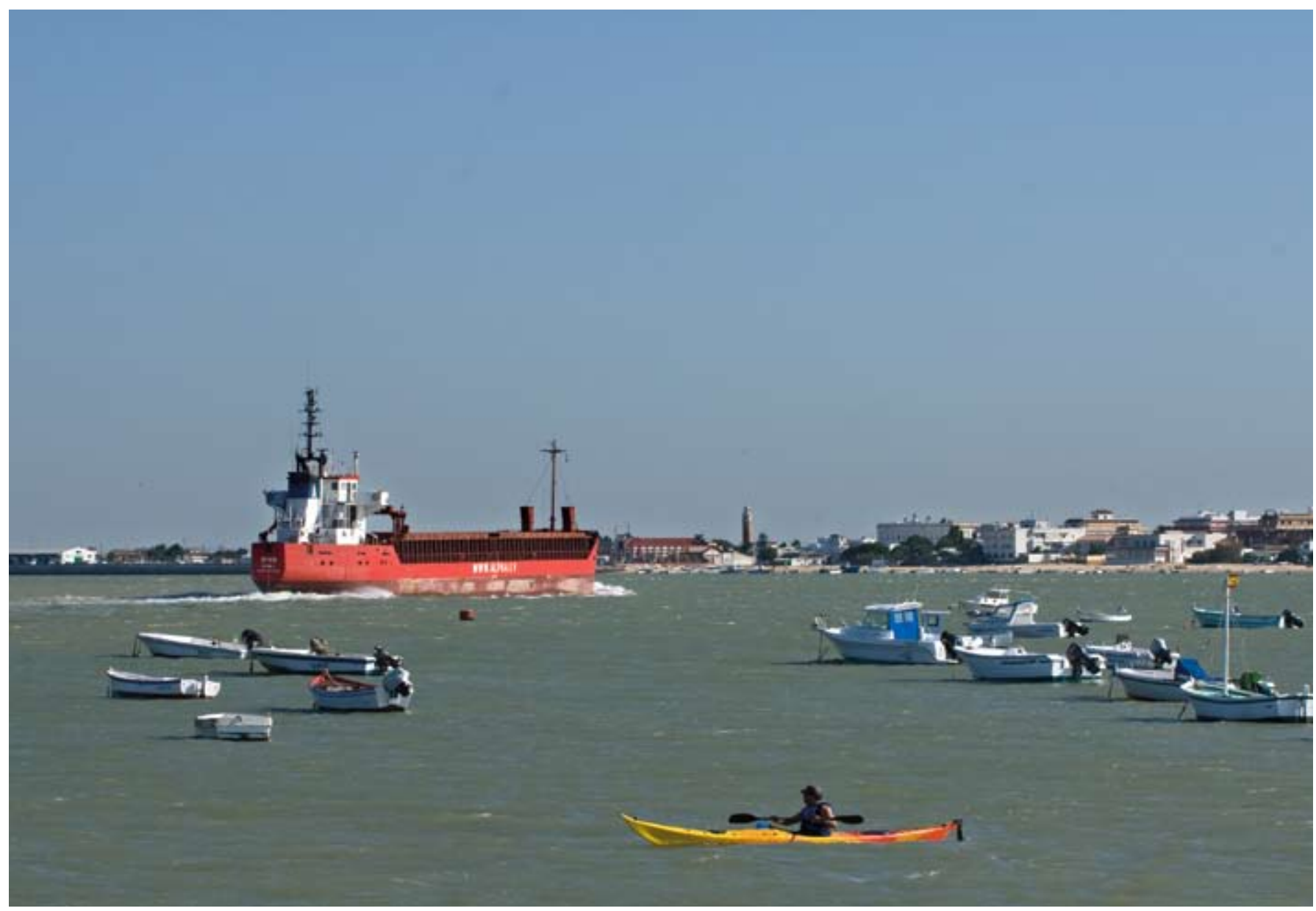

La desembocadura del Guadalquivir en el término de Sanlúcar de Barrameda conforma un paisaje único donde limitan las provincias de Cádiz y Huelva con el Parque Nacional de Doñana en la parte onubense. Foto: Juan Carlos Cazalla, IAPH

\section{La desembocadura del Guadalquivir}

Generada a partir de la aportación de sedimentos por parte del Guadalquivir y creada a raiz de la confluencia entre el mar y la desembocadura de un río, la mirada hacia la desembocadura del Guadalquivir como paisaje cultural implica hacer un recorrido por aquellos elementos y actividades culturales presentes a lo largo de su historia que han contribuido a la generación de este excepcional paisaje cultural.

Geográficamente este paisaje, que para unos es percibido como frontera y para otros como puente, pertenece, en su banda izquierda, a la localidad de Sanlúcar de Barrameda -provincia de Cádiz-, mientras que en su banda derecha -provincia de Huelva-, se localiza unos de los espacios naturales más importantes a nivel europeo, el Parque Nacional de Doñana, en este caso en la zona sur del municipio de Almonte. Se trata, por tanto, de un paisaje cultural generado a través de la presencia de un río y su desembocadura que, aunque legalmente pertenezcan a provincias distintas, no se pueden entender sin atender a los diferentes procesos geológicos que han configurado la zona y a las sucesivas actividades desarrolladas a lo largo de la historia de un río como el Guadalquivir, una arteria fundamental para la historia del territorio andaluz.
Y es que hablar del Guadalquivir implica hablar de un río a través de cuyas aguas nuestro territorio ha recibido la influencia de gentes que dejaron su impronta en el paisaje andaluz y forjaron nuestra identidad como pueblo. De esta forma, en sus oriIlas podemos admirar las huellas más visibles que dejaron romanos, árabes y conquistadores cristianos, claros exponentes de un sincretismo cultural que la población andaluza ha custodiado con orgullo.

El Guadalquivir ha sido también canal de comunicación entre América y Andalucia, puerta de entrada a Europa y vía de salida hacia el Nuevo Mundo. Por ello, no ha sido nunca para los andaluces una frontera, sino también un puente que ha permitido nuestro enriquecimiento cultural a través de la filosofía, las artes y las ciencias. Por ello, además de comunicarnos con el mundo, esta arteria fluvial y toda su cuenca hidrográfica han vertebrado nuestro territorio, conectando pueblos y ciudades y bañando sus orillas como testigo atento $y$ artífice activo de su historia.

En la zona de su desembocadura, todas las cuestiones mencionadas se sintetizan y hacen evidentes a través del ingente patrimonio cultural -tangible e intangible- y natural que ha llegado hasta nuestros dias: las factorías de salazón localizadas en la zona de la Algaida de Sanlúcar de Barrameda y en el Cerro del Trigo en el actual Parque Nacional de Doñana, la histórica explotación de las salinas en ambos márgenes; el desarrollo de técnicas especificas para la pesca cuya práctica derivó en la construcción de corrales marinos y la creación de zonas para el fondeo de barcos en la orilla sanluqueña de forma paralela a la configuración de barrios pesqueros, caso del de Bajo de Guía, que han llegado hasta nuestros dias como importantes referentes gastronómicos surpralocales. En la misma línea se deben resaltar la aparición y consolidación del Puerto de Bonanza y su lonja, y el desarrollo de unas prácticas gastronómicas construidas en torno a las materias primas de la desembocadura y los usos marineros. Todos estos elementos, actividades y procesos, forman parte de un paisaje cultural de honda raigambre histórica, donde ha tenido y tiene lugar una significativa fusión entre elementos culturales y naturales.

Isabel Durán

Centro de Documentación, IAPH 


\section{El viñedo de Jerez. Arquitectura y paisaje del vino}

José Manuel Aladro Prieto, Dpto. de Historia, Teoría y Composición

Arquitectónicas, Universidad de Sevilla
A mediados del siglo XIX Antoine Latour nos dejaba esta descripción cargada de poesía: "Jerez la ciudad de los viñedos [...] Inmensos campos de viñas, [...], separados por setos de aloe y chumberas, dragones erizados, colocados para custodia de estos jardines de Hespérides". Como al romántico francés, la viticultura jerezana suscitaria una especial atención de científicos y viajeros decimonónicos. Entonces y ahora, la vid se identificaba como uno de los más representativos elementos identitarios de la campiña jerezana. A pesar de ello nunca ha supuesto más que un pequeño porcentaje del amplio territorio dedicado a la tierra calma. Esta identificación, que se corresponde desde luego con su alta cualificación agrícola, deriva ante todo del complejo entramado de relaciones socioculturales que han configurado históricamente la agroindustria del Jerez, y que constituye esencia indiscutible del patrimonio cultural gaditano.

Casas de viñas y bodegas son las dos caras del Jerez, rural y urbana, que han evolucionado histórica y culturalmente de forma paralela. Presentes en la comarca desde la antigüedad', la consolidación del paisaje del viñedo, tal como hoy lo valoramos, está intimamente ligada a la modernización que experimentó la industria vitivinicola a partir de mediados del siglo XVIII. En estas fechas "en el Marco del Jerez se libró uno de los conflictos más interesantes entre el Antiguo Régimen y el liberalismo de los habidos en España" que supuso la radical transformación del sistema tradicional de producción y comercialización ${ }^{2}$. La nueva estructura industrial, capitalista, burguesa y liberal, se convertiría en menos de un siglo en un fenómeno de escala nacional desconocida. En 1850 la exportación del Jerez supuso algo más del 50\% de los beneficios que produjo el comercio exterior español.

Este proceso, en el que surgirian las grandes empresas verticales que habrian de controlar desde la tenencia de la tierra hasta la exportación de los caldos, supondría el inicio auténtico de la modernización de la agricultura andaluza y una "verdadera punta de lanza del capitalismo y economía españolas"3. Desde mediados del XVIII la burguesía vinatera había iniciado su implantación terri- torial incrementándola progresivamente. La superficie vitícola a finales del siglo XIX duplicaba las poco más de 9000 aranzadas $^{4}$ existentes a mediados del siglo anterior, y el número de casas de viñas se elevaba desde las 555 de 1792 a 826 en 1839. En la actualidad, la mayor parte de las casas históricas existentes provienen de este momento. De su origen temporal derivan en buena medida su condición singular dentro de la arquitectura agraria andaluza, su homogeneidad y concepción tipológica.

El viñedo reitera el modelo latifundista del cereal, aunque sin alcanzar nunca las dimensiones de éste. Una minoria de grandes explotaciones, sobre todo en Jerez y El Puerto, y gran cantidad de pequeñas propiedades en los términos de Sanlúcar, Trebujena y Chipiona. Esta estructura dual, procedente del Antiguo Régimen y reforzada tras las desamortizaciones y la crisis filoxérica (1894), se caracterizó históricamente por la existencia de una o varias casas en cada finca, incluso en las de escasas dimensiones. En 1818, casi la mitad de las cerca de mil fincas inventariadas, a poco que superaran las cinco o seis aranzadas, disponian de casa y las de mayor tamaño contaban a veces con dos o tres casas y varios lagares.

Tras la replantación obligada por la filoxera, el paisaje viticola hoy histórico se concentró en la campiña noroeste, al Oeste de la vía férrea de Madrid a Cádiz, entre las tres principales ciudades del Marco: Jerez, Sanlúcar y El Puerto. Este paisaje formalizado en lomas de suaves pendientes surcadas por carriles y abundantemente salpicadas por pequeñas casas de viñas, es el resultado de la superposición compleja de factores físicos, agrícolas y parcelarios, y de la suma de parámetros de índole cultural, social, y económico, locales y nacionales, que están en la base de su propia generación. Frente al cortijo y a la hacienda, exponentes y herederos de concepciones económicas y compositivas del Antiguo Régimen, las casas y el paisaje vitícola, generados dentro del proceso de modernización y consolidación del capitalismo bodeguero, son hijos de la renovación neoclásica, del racionalismo ilustrado del XVIII y de los planteamientos económicos y progresistas del capitalismo burgués del XIX. 

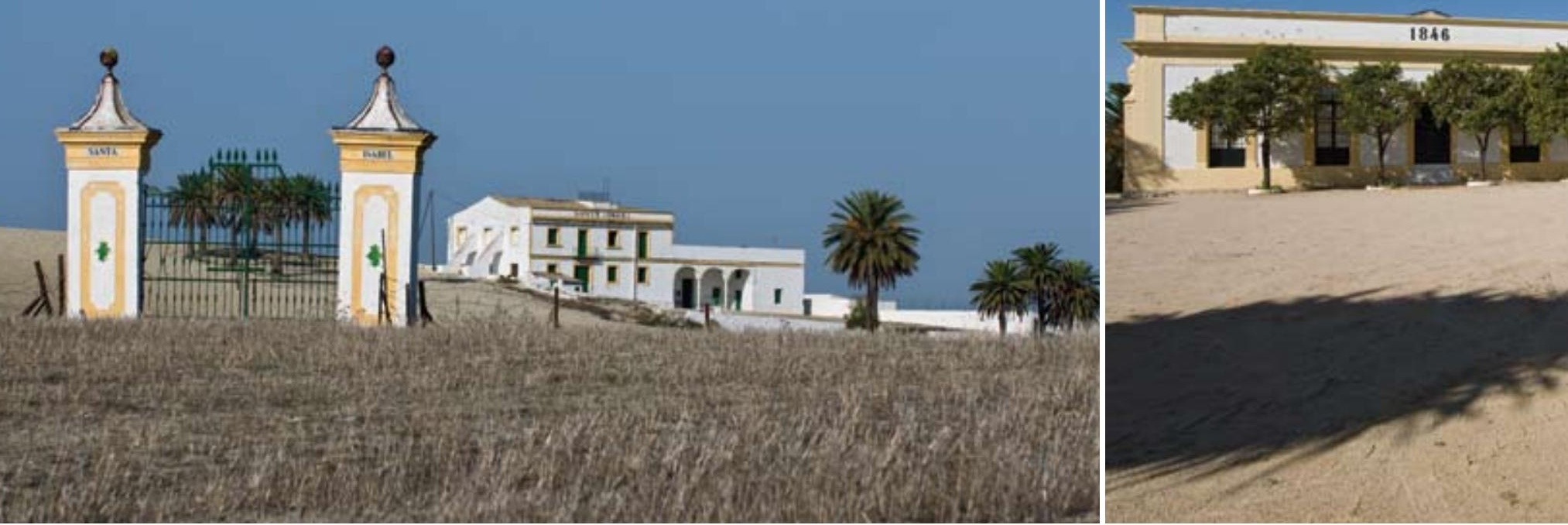

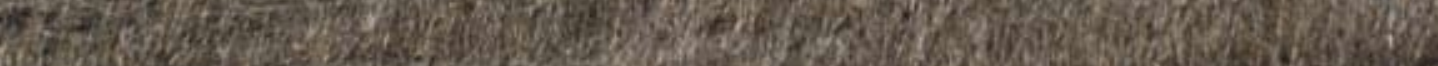

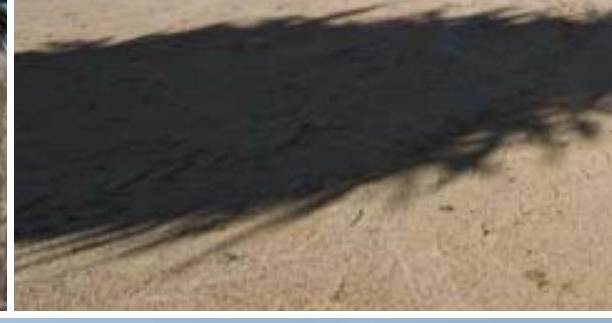

\section{(2)}

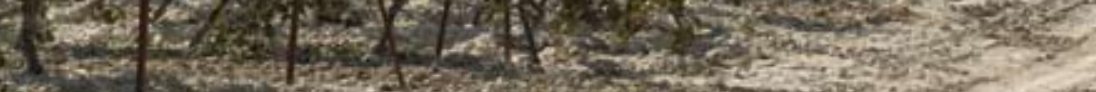

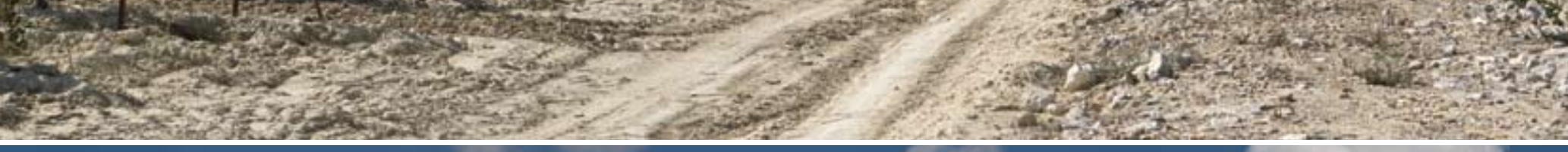

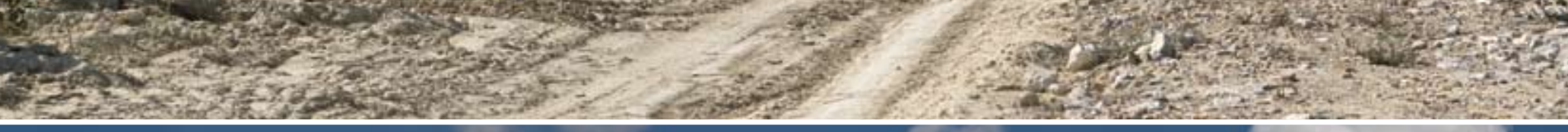

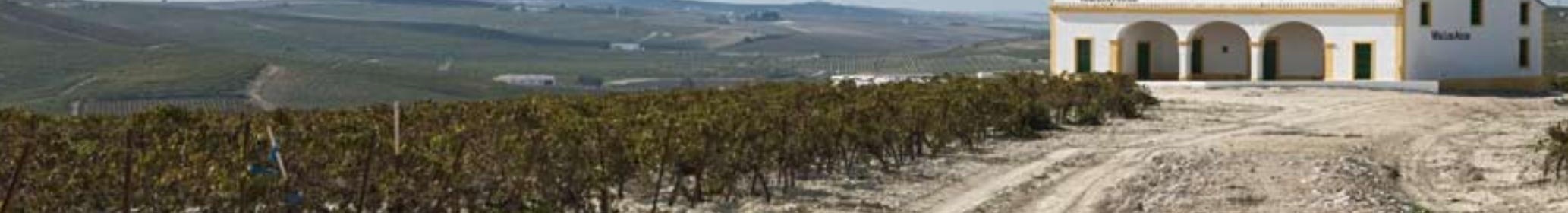




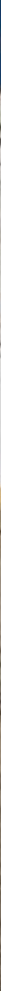

La singularidad y homogeneidad del modelo tipológico de la casa de viña del Marco del Jerez en el conjunto

de la arquitectura agraria andaluza procede en buena medida de su condición temporal, del contexto económico y cultural, capitalista y burgués, en que se consolida el modelo constructivo y productivo. Fotos: Juan Carlos Cazalla, IAPH

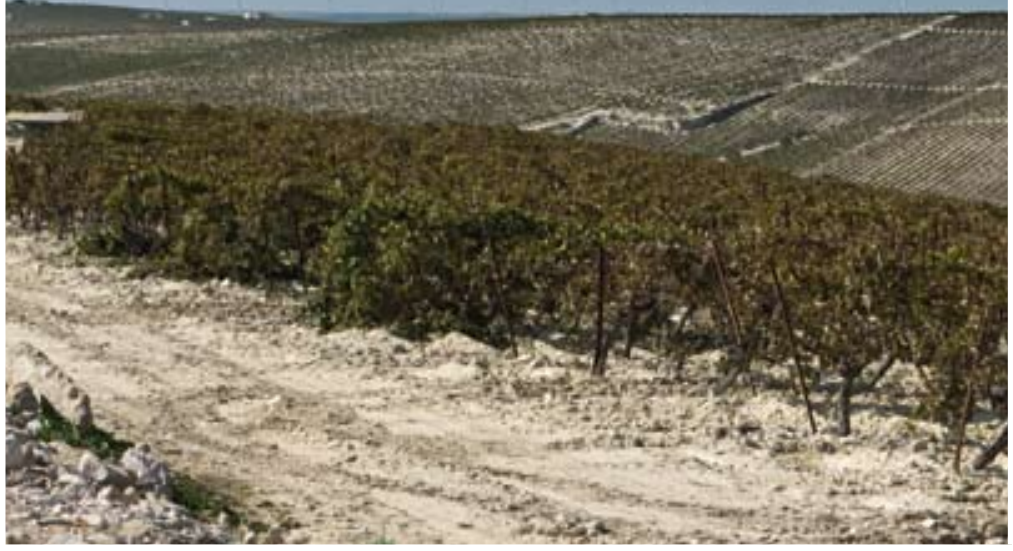

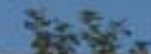

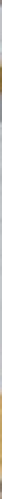




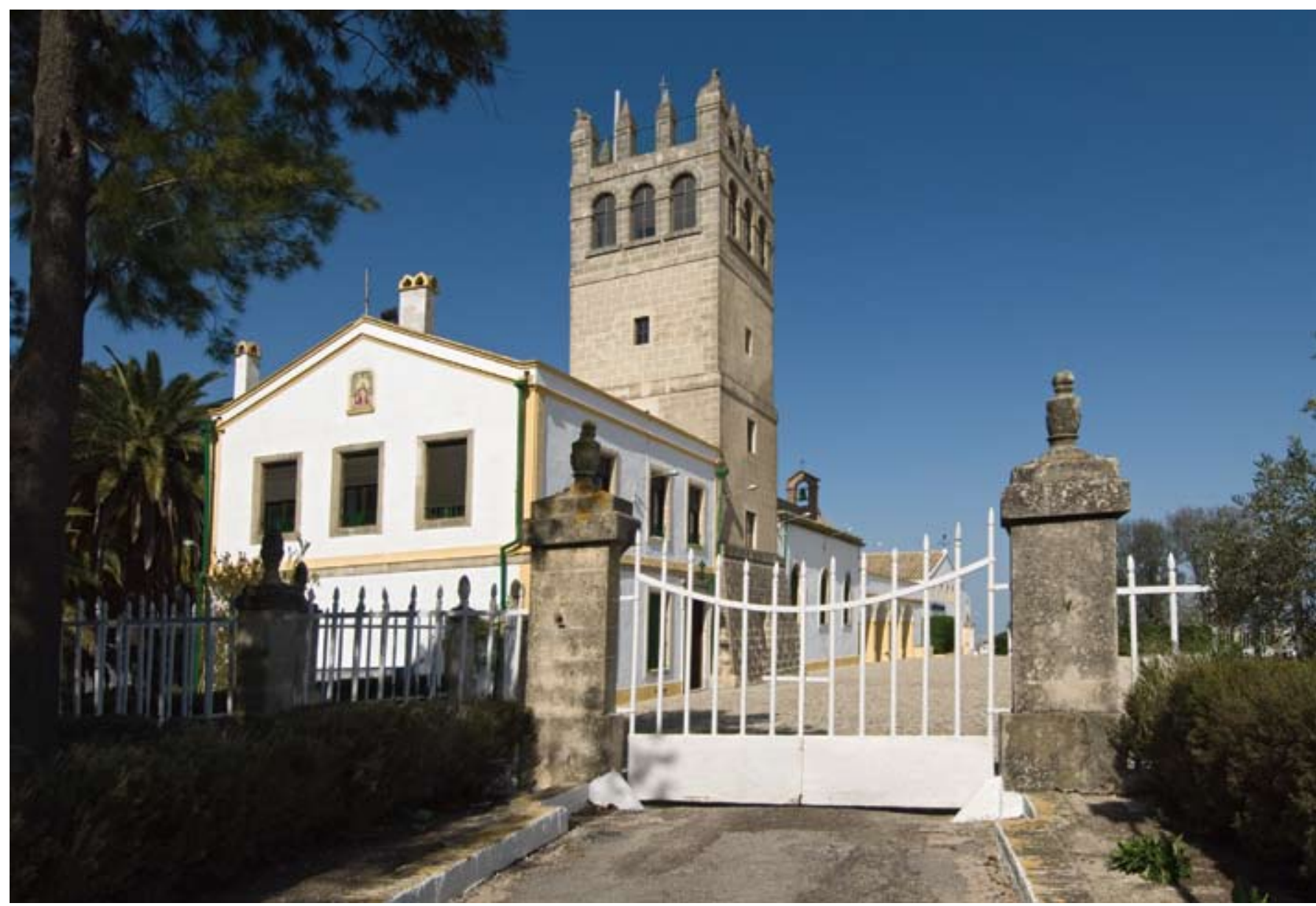

Macharnudo o Cortijo de El Majuelo. Casa de viña, cabecera de la explotación de Domecq, que asume el protagonismo real y simbólico de la explotación. Foto: Juan Carlos Cazalla, IAPH

Las casas, como las bodegas urbanas, son fundamentalmente contenedores arquitectónicos, casi neutros, constructivamente básicos. Compactas, racionales y moduladas, acogen bajo una misma cubierta las distintas funciones, normalmente en bandas paralelas coincidentes con muros y pilares. Construidas principalmente para albergar la pisa de la uva, el sistema tradicional de extracción del mosto, no tienen ningún condicionamiento tecnológico mayor que el de proporcionar un espacio amplio y aireado a los lagares: "El edificio de una viña se compone de dos partes: la casa de lagares y bodega. La casa de lagares es el local destinado a contener estos, que consisten en un cajón de madera de roble de seis varas en cuadrado [...] La bodega de la viña es una sala donde se deposita provisionalmente el mosto para ser conducido después a la ciudad"5. Además de estas dos, solian contar con dependencias para los aperos de labranza, cuadra y vivienda para el capataz. También contaban, habitualmente, con una sala para el personal, la casa de la gente o fogarin. Las bodegas, aunque habituales, no eran imprescindibles, pues el mosto se trasladaba inmediatamente a la ciudad.

El elemento externo más definitorio es el portal, espacio horadado al volumen de la casa que da acceso al lagar. Al exterior, frente al portal, se sitúa la explanada del almijar, dependencia a cielo abierto para el soleo de la uva previo a la pisa. La portada de ingreso a la finca, el aljibe o el propio camino de acceso, también forma parte del conjunto. Elementos y espacios que establecen un itinerario, una secuencia, que supera lo meramente construido, y que alcanza un sentido casi procesional, una dimensión territorial y paisajística. Desde la portada se avanza entre vides hasta el almijar, aterrazamiento necesario, primer rasgo colonizador y apeadero de la casa. El portal, filtro ante el sol y el agua, nos conduce al lagar, donde nace el vino, origen y fin del itinerario.

Este sentido territorial se refuerza en la coexistencia de varias casas dispersas dentro de una misma propiedad, a escasa distancia unas de otras, con cierta independencia productiva, pero formando parte de un conjunto en el que todo está interrelacionado. El emblemático viñedo de Majuelo, en el pago de Macharnudo, (adscrito a Domeca casi desde los orígenes de la firma) contaba en 1818 con tres construcciones independientes, con alambique, bodegas y hasta quince lagares. A principios del siglo XX, tras la concentración posterior a la filoxera, estaba "dividido en cuatro secciones enlazadas por bien construidos y cuidados arrecifes", en las que se ubicaban cuatro casas con lagares, bodegas y dormitorios: Viña Ponce, Cerrón, Picón, y La Casa Grande o Castillo de Macharnudo, y "otras más modestas" que son Ardila, con lagares y dormitorios, Alamera, almacén, El Panadero, dormitorios, y El Notario, casa de guardas. Un conjunto de construcciones dispersas que asumian una cierta especialización. Algunas incluso funcionaron como escuelas o tuvieron capilla para el servicio dominical de los empleados. Entre todas, una actuaba como cabecera de la explotación, incluyendo habitaciones para la propiedad y asumiendo una mayor carga ornamental y representativa: el Castillo de Macharnudo en Domecq o la Canariera en González Byass. 

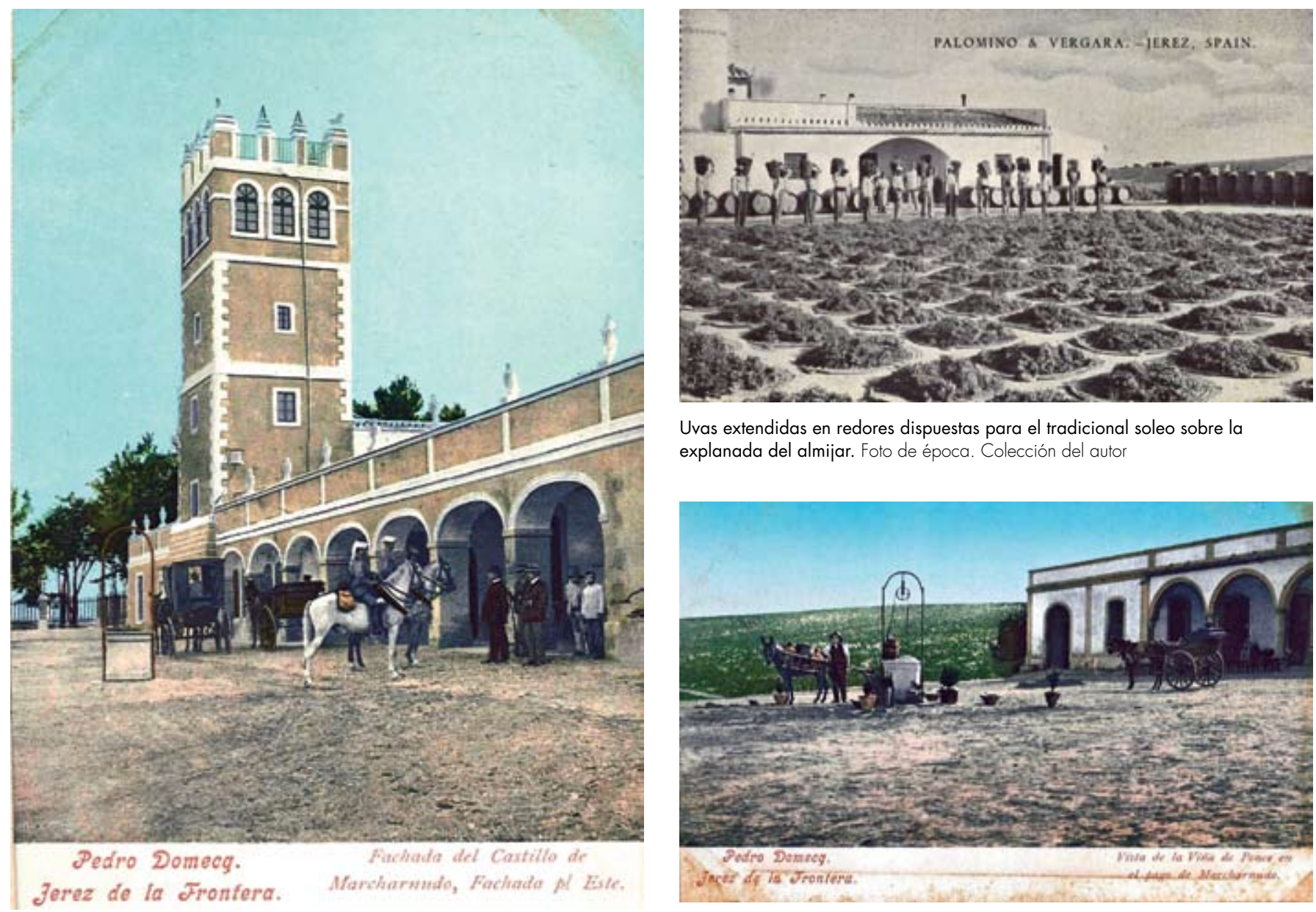

Uvas extendidas en redores dispuestas para el tradicional soleo sobre la explanada del almijar. Foto de época. Colección del autor

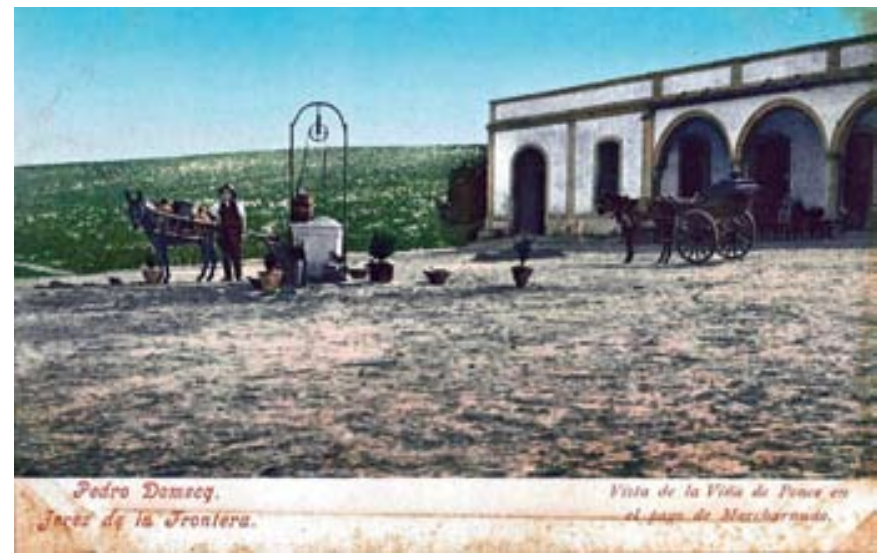

Fotografías iluminadas de principio de siglos XX. Postales publicitarias de la casa comercial Pedro Domecq: la viña Castillo de Macharnudo, cabecera de la explotación, y Viña Ponce. Imágenes digitales del autor

Conceptual y cronológicamente la territorialidad derivada de la estructura anterior se enmarca en el conjunto de reformas borbónicas e ilustradas que desde mediados del XVIII tratan de definir el territorio como una unidad de orden administrativo y económico, en la que todos los elementos forman parte de una entidad global. Desde la lógica burguesa el suelo es un elemento más del proceso productivo, y lo económico uno de los aspectos predominantes en la definición del territorio. Bajo esta percepción, las casas rechazan la tradicional introversión de la arquitectura rural, aceptan el enfrentamiento con el paisaje abierto y se exponen a él. Los portales se abren al paisaje desde oteros elevados con alardes de evidente fachadismo sorpresivo en el territorio.

De forma análoga a lo que está sucediendo en las ciudades del Marco, la burguesía bodeguera ha protagonizado un proceso de ordenación y control del territorio cuyo objetivo último es su puesta en explotación. Caminos, portadas, edificaciones y plantaciones se ordenan en una estructura global que da sentido a cada elemento y cuya expresión es el propio paisaje.

La actividad vitivinicola ha sido pilar fundamental de la historia de la campiña jerezana, por lo que cualquier manifestación de la misma comporta una dimensión patrimonial de incalculable valor. Las construcciones del viñedo, además de su valor intrínseco como arquitectura, especialmente relevantemente como conjunto tipológico, son en esencia testimonios construidos de un conjunto de saberes y valores de carácter etnográfico, que exceden en mucho lo arquitectónico y que hacen referencias a sistemas productivos, modos de vida, o a formas de relacionarse el hombre con el medio. Constituyen parte de un paisaje que es en sí mismo patrimonio cultural, paisaje cultural en el sentido que la UNESCO confiere a este término. Tras décadas de inacabada crisis industrial y sucesivos planes de arranque de viñedos, la valoración patrimonial de este paisaje, la relectura de su legado cultural, se hace hoy más evidente y quizás necesaria que nunca.

\section{Notas}

${ }^{1}$ En el yacimiento arqueológico de Doña Blanca (El Puerto de Santa María) se han encontrado importantes vestigios de lagares de época fenicia

2 MALDONADO ROSSO, J. (1997) Imágenes y realidades de la historia y la cultura contemporáneas del Jerez-Xeres-Sherry. Demófilo. Revista de Cultura Tradicional de Andaluciá, n²4, 1997, p. 221.

${ }^{3}$ MIGUEL BERNAL, A. (1984) Señoritos y jornaleros la lucha por la tierra. En MIGUEL BERNAL, A. (dir.). Historia de Andalucia VI, La Andalucía Liberal. Madrid: Editorial Planeta, 1984, pp. 239-240.

${ }^{4}$ Equivalencia de la aranzada: 1 aranzada $=0,4472$ hectáreas

${ }^{5}$ LIZAUR Y PAÚL, D. (1887) Cultivo de la vid y fabricación del vino en la provincia de Cádiz. Gaceta Agrícola del Ministerio de Fomento, vol. V, 1877, pp. 718-728. 


\section{El expediente de protección de las bodegas de Sanlúcar de Barrameda}

Por encargo de la Delegación Provincial de Cultura de la Junta de Andalucía en Cádiz iniciamos en septiembre de 2007 -José Manuel Aladro Prieto, arquitecto, y el que esto suscribe- el expediente de catalogación genérica colectiva de los espacios bodegueros de Sanlúcar de Barrameda. Asumimos el compromiso profesional con gran interés, entusiasmo y, por qué no decirlo, cariño y responsabilidad. La tarea se antojaba ardua y dificultosa.

El ingente volumen de bienes inmuebles que se enmarcan dentro de este conjunto patrimonial -149 referencias catastrales identificadas que aglutinan alrededor de unos 200 cascos de bodegas-, la fuerte especulación inmobiliaria a la que están sometidos, su acelerada desaparición, el escaso, cuando no nulo, grado de protección del que gozan en los planeamientos municipales y/o autonómicos, la suspicacia y reticencia que nuestras pesquisas levantaban entre muchos de los propietarios con los consecuentes problemas de accesibilidad que esto ha provocado $y$, por último, la urgencia con la que se hace necesario intervenir han sido los condicionantes bajo los que hemos desarrollado nuestro trabajo.

La metodología empleada ha sido diversa y acorde a la complejidad del conjunto patrimonial objeto del estudio. La web del Aula de Investigación Histórica Gerión (www.gerionsanlucar.com), colectivo fuertemente implicado en la defensa del patrimoio sanluqeño, nos ayudó sobremanera a la hora de tomarle el pulso a la situación.

Procedimos después al vaciado de bibliografía especializada tanto en arquitectura bodeguera como en aspectos históricos, sociales y culturales asociados a Sanlúcar de Barrameda y a su vinicultura. Consultamos también cartografia, fotografia aérea y planimetría de inmuebles y conjuntos bodegueros concretos. Esto, junto a las colecciones fotográficas y los grabados históricos, nos ha permitido rastrear la evolución y modificaciones que han experimentado las construcciones bodegueras, la relación que éstas mantienen con el resto del conjunto urbano, las áreas donde tradicionalmente se han localizado, asi como los cambios de ubicación que esta actividad productiva ha experimentado.

Pero sin duda alguna, la información más valiosa nos la han ofrecido las visitas -más de treinta- realizadas al campo de trabajo. Para ello, partimos de la parcelación establecida en el Documento de Avance de la Revisión-adaptación del PGOU de Sanlúcar de Barrameda de Septiembre 2006. En un primer acercamiento, nos dedicábamos a observar y analizar el exterior de los complejos bodegueros -su estado de conservación, uso que reciben en la actualidad, relación que mantienen con los edificios circundantes- para posteriormente concertar visitas con los propietarios y acceder al interior de los distintos cascos. Desafortunadamente esto no ha sido posible en todos los casos ya que nos hemos encontrado con inmuebles en desuso, algunos en avanzado estado de derrumbamiento, a cuyos propietarios no hemos logrado localizar.

Durante estas visitas tomamos fotografias tanto de exteriores como de interiores que, junto a las descripciones de los inmuebles, las fotografias aéreas y los planos de las parcelas catastrales conforman las fichas que incluimos en el informe final que estamos ultimando. Además, con objeto de dotar a este inventario de una sólida justificación etnográfica, realizamos paralelamente entrevistas no formalizadas y abiertas a bodegueros, empleados y otros miembros de la población local ajenos al sector con la intención de obtener información privilegiada sobre saberes productivos, procesos de transmisión y sociabilidad, dimensión simbólica, identitaria y económica de la actividad, etc.

La especial relevancia de la arquitectura bodeguera en la configuración del entramado urbano sanluqueño da muestras de la vocación vinícola de esta localidad así como de la importancia y arraigo que esta actividad productiva ha tenido para la economía de la zona. Hemos podido contrastar, no obstante, cómo el sector vinicola, sin dejar de ser importante, ha perdido centralidad económica a favor de otras actividades. Ello explica el pesimismo generalizado que existe con respecto al futuro del sector bodeguero y de la arquitectura asociada a él. A modo de metáfora, esta diversificación en las fuentes de ingreso tiene también su reflejo en el desplazamiento hacia el extrarradio que algunas de las firmas bodegueras más emblemáticas viene experimentando en los últimos años. Obviamente, la búsqueda de mayor operatividad y funcionalidad en las nuevas instalaciones ha inspirado también estas estrategias empresariales.

A nivel simbólico, el caso de Sanlúcar de Barrameda resulta paradigmático ya que, a pesar de que en esta localidad se elaboran los vinos genéricos del Marco del Jerez, se produce una identificación de gran calado entre un tipo especifico, la manzanilla, y esta población, que opera tanto en el interior como en el exterior de la misma. Por encima de la fuerte estratificación social que la industria bodeguera de esta zona ha generado y en base al especifico y exclusivo origen local de la manzanilla, este vino se constituye en "patrimonio común de todo el pueblo" de Sanlúcar (GÓMEZ DíAZ, Ana Maria: La Manzanilla. Historia y Cultura. Las bodegas de Sanlúcar. Sanlúcar de Barrameda. Pequeñas ideas editoriales, 2002) llegando a impregnar prácticamente todas las esferas de la vida cotidiana: ciclo festivo -Feria de la Manzanilla, Carreras de Caballos en Bajo Guía-, gastronomia, ámbitos de sociabilidad...

Así, son interesantes las pautas de consumo, diferentes, al menos en parte, a las apreciadas en otras localidades del Marco. Por ejemplo, la venta a granel extendida y generalizada incluso entre las firmas más potentes del sector, el uso de utensilios y elementos característicos como la venencia de caña, los vasos de caña en bandejita metálica que se utilizan para la manzanilla en vez del catavino, el empleo de una terminología propia, etc. Pero quizás el ejemplo más claro de la importancia que posee la manzanilla a nivel simbólico e identitario lo encontremos en la personificación, la feminización para ser más exactos, de la que es objeto este vino. Tanto los nombres comerciales que se le atribuyen como las representaciones, ilustraciones o personajes históricos con los que se asocia forman parte del universo femenino.

También hemos encontrado peculiaridades significativas en el plano arquitectónico. Por ejemplo hemos detectado en las bodegas sanluqueñas una mayor presencia de elementos metálicos, una mayor profusión en el uso del hierro y de elementos decorativos y ornamentales que se toman, en muchos casos, de la arquitectura popular. Otras soluciones arquitectónicas observadas han sido las cerchas de madera utilizadas para salvar grandes luces, los bajetes de piedra ostionera que se utilizan como soporte de las botas, o las puertas de rastrillo que comunican unos cascos de bodega con otros. Por último habría también que comentar que en Sanlúcar se produce una curiosa simbiosis, una mezcolanza entre distintos espacios "sagrados", por una parte los conventos e iglesias que se convierten en bodegas y por otra las bodegas que recuerdan a catedrales y santuarios.

Confiamos en que este trabajo contribuya de forma integral a la conservación y puesta en valor de este conjunto patrimonial tan característico de la Revolución Industrial Andaluza. Es decir, que no se atienda exclusivamente a su dimensión material, arquitectónica y urbana sino que se contemplen igualmente sus valores simbólicos, identitarios e ideológicos.

\section{Julio de Vega López}

Antropólogo 


\section{La ganadería brava como patrimonio natural en la zona de la Campiña de Jerez y Medina Sidonia}

Manuel Sotelino, Periodista

Si partimos del dato estadístico que la Unión de Criadores de Toros de Lidia nos da en el año 2005, son treinta y tres ganaderías de lidia en la provincia de Cádiz las adscritas a esta asociación de ganaderos de primera. Cádiz ocupa, en cuanto a número de hierros, el tercer lugar de toda España, sólo superada por Sevilla y Salamanca.

Esto nos da una idea bastante aproximada de la importancia patrimonial de este maravilloso bovino tan unido a nuestra cultura mediterránea desde tiempos de Estrabón, el cual ya nos informaba en sus escritos sobre la gran cantidad de toros bravos que campaban a sus anchas por las tierras de Iberia. Es un valor que, con el paso de los siglos, se ha ido acrecentando, fundamentalmente, como soporte de otro interesante marco de conservación patrimonial como es el meramente paisajistico y, por ende, la conservación de nuestro marco ecológico y natural.

Centrándonos en la zona de la campiña jerezana y Medina Sidonia, corazón, sin duda, de nuestra provincia de Cádiz, si miramos desde la zona de El Cuervo, con la ganadería de Rocío de la Cámara, hasta el sur donde se crian los afamados toros santacolomeños de la familia Carrasco Romero, en el término municipal de Alcalá de los Gazules; o desde la zona de El Puerto donde siempre estuvieron los toros de Osborne y de José Luis Sánchez, hasta la parte más oriental donde podemos encontrar la ganadería de Salvador Domecq, existen explotaciones y fincas en el que el toro es el auténtico rey de la dehesa. Se trata de un aprovechamiento certero que ha conseguido mantener el monte medio y bajo en perfecta sintonía con el entorno natural. Podemos afirmar sin temor a equivocarnos que, gracias a la crianza del toro bravo en la provincia de Cádiz, se ha podido mantener gran parte del bosque mediterráneo, donde el quejigo y el alcornoque conviven con la carrasca y el lentisco. Son terrenos libres de cualquier tentación devastadora que busque la rentabilidad de una explotación agrícola que hubiera dado al traste con la conservación de la naturaleza y la fauna autóctona a la que todos debemos de estar llamados.

\section{PEQUEÑA RESEÑA HISTÓRICA}

Antes de volver a la explotación ganadera, a sus costumbres y a sus tareas, así como a las faenas de campo propiamente dichas, seria interesante hacer un brevisimo repaso histórico, al menos del último siglo, para señalar la presencia del ganado bovino de lidia en la zona que nos compete. En las tierras albarizas de los alrededores de El Portal, en las fincas Las Quinientas y Roalabota, han pastado, desde 1914, los toros del marquesado de Villamarta. Fue don Álvaro Dávila Ágreda quien comenzó con la labor ganadera, consiguiendo la cría de un cornúpeta idóneo para el toreo de la época bajo el cruce de castas tan dispares como las de Veragua -vía Medina Garvey- Urcola, Murube, Parladé o Santa Coloma. El método genético arrojó sus resultados y en los campos de Las Quinientas siempre hubo toros bravos.

Asimismo, también sabemos de la labor de don Enrique Queralt y Maqueira, Conde de Santa Coloma, en nuestras tierras gaditanas. En Jerez poseía el cortijo del Chorreadero, que está al este de la carretera de Paterna a Arcos, antes de llegar a los Baños de Gigonza, y que hoy pertenece en parte a San José del Valle. Curiosamente, estas tierras poseen unas interesantes ruinas romanas. Posiblemente, a primeros de siglo, pastaron alguna de las reses del conde en esta finca gaditana.

Pero la presencia más importante en la zona, la que imprime más carácter e identifica al toro bravo con la campiña jerezana y la zona de Medina Sidonia, la trae Juan Pedro Domecq Núñez de Villavicencio cuando en 1930 compra la totalidad de la vacada del duque de Veragua que pastaba en Aranjuez. Esta ganadería procedía directamente del tronco que formara, en 1780, José Vicente Vázquez en tierra utrerana con reses de Casa Ulloa, Bécker, Cabrera y Vistahermosa. Posteriormente, y gracias a la importante colaboración de Ramón Mora Figueroa -ganadero que sobrevive en la historia de la tauromaquia casi en lo secreto pero que tuvo gran importancia en esta fase embrionaria de lo que sería el toro gaditano, la ganadería de la familia Domecq-, 


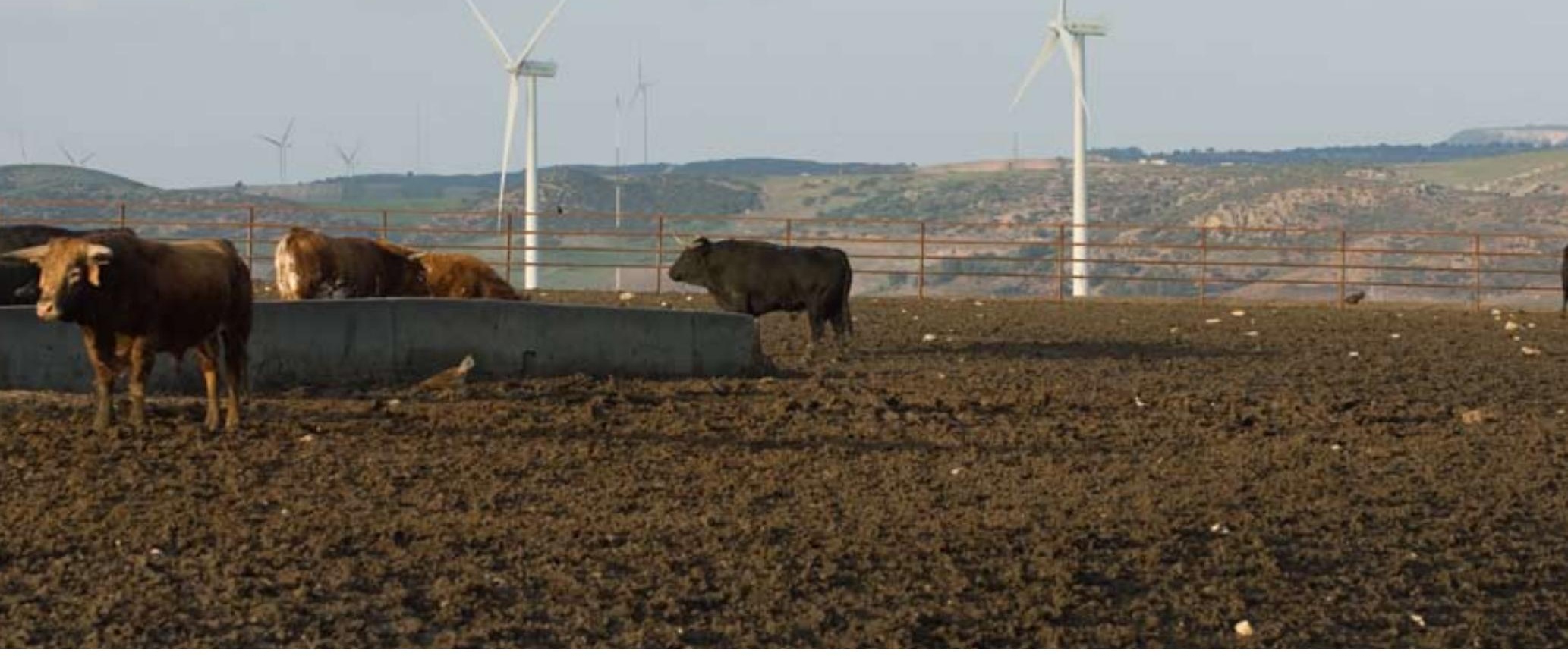

Una imagen no poco frecuente en los paisajes de esta comarca: los toros bravos pastan junto a los enormes molinos de energía eólica (arriba y derecha). Foto: Juan Carlos Cazalla, IAPH

El encaste Domecq se ha ido prodigando en muchas vacadas actuales que se nutren de su sangre, habiendo toros de este encaste en toda la geografía de nuestra zona gaditana. Desde los campos jerezanos de Martelilla hasta la zona de Medina Sidonia, con fincas como La Quinta, La Zorrera, El Toñanejo o Los Alburejos dejó sus orígenes vazqueños para ser lo que hoy día vemos: el toro de encaste Vistahermosa por la rama Parladé - Conde de la Corte y García Pedrajas.

El encaste Domecq se ha ido prodigando en muchas vacadas actuales que se nutren de su sangre, habiendo toros de este encaste en toda la geografía de nuestra zona gaditana. Desde los campos jerezanos de Martelilla hasta la zona de Medina Sidonia, con fincas como La Quinta, La Zorrera, El Toñanejo o Los Alburejos.

\section{CRIANZA, CUIDO Y SELECCIÓN}

Las ganaderias de reses bravas son, fundamentalmente, un laboratorio de selección de nuestra raza autóctona bovina destinada a la lidia en las plazas de toros. Como tal, estas explotaciones están concebidas para la cría del ganado de forma extensiva y de manera totalmente natural. La mano del hombre está fundamentada en dos grandes apartados: la selección de las reatas más aptas para la lidia y el cuidado en las mejores condiciones de las reses aprobadas.

Para la selección, cada finca cuenta con el soporte donde se va a dirimir el camino de la ganadería y del comportamiento bravo de 


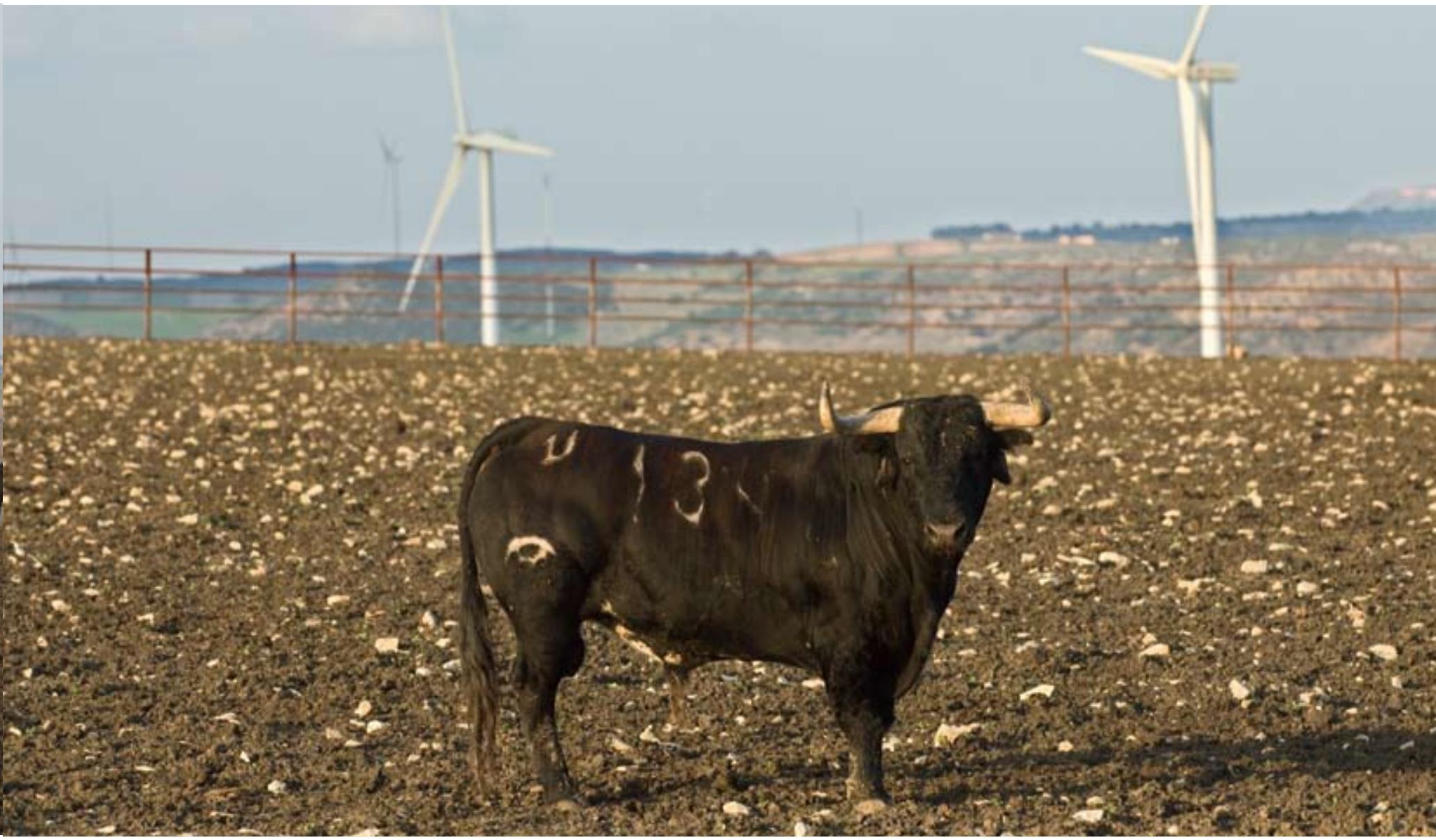

las reses que cuida. Este emplazamiento es la plaza de tientas. Es el lugar donde el ganadero, ayudado por el conocedor, selecciona aquellas hembras que mejor comportamiento han tenido en la tienta, y que se fundamenta en la acometividad de la res en el caballo y en la forma de embestir a los engaños. Rebosarse con clase yendo a coger los flecos de la pañosa con bravura, fuerza y codicia. Las camadas de eralas pasan todas por la plaza de tientas. Los machos son seleccionados para ser tentados tras vérseles hechuras y reata, es decir, estudiando los libros genealógicos y eligiendo aquellos erales o utreros que, por familia, merecen ser vistos para ser futuros progenitores si salvan la dura prueba de la tienta. Éstos pasarán en principio a ser sementales de prueba, se les observarán las crías que ha dado dos años más tarde $y$, si los objetivos están cumplidos al dar descendencia brava, pasarán a ser sementales contrastados.

Las demás faenas de campo están encaminadas al mejor cuido de las reses que pastan en la finca. A los diez meses, más o menos, llega el herradero, que es la faena de campo donde se marca e identifica con un número las cabezas de ganado que van a ser destetadas de sus madres. Es una faena que siempre ha ido acompañada de un cierto tono de fiesta, acabándose siempre la labor con un buen cocido campero mientras las crias berrean echando de menos las ubres de sus madres.

\section{En la web}

\section{AULA DE INVESTIGACIÓN HISTÓRICA GERIÓN}

http://www.gerionsanlucar.com/

Web de la Asociación cultural para la investigación y fomento de la historia y el arte y la defensa del Patrimonio Histórico de Sanlúcar de Barrameda. Además de ofrecer información general sobre la asociación, sus origenes y funcionamiento, cuenta con una sección para publicar artículos de opinión enviados por los interesados y otra para noticias. También incluye un blog para participar en debates sobre diversos temas y otra página de enlaces.

\section{ARCHIVO DE LA FUNDACIÓN CASA MEDINA SIDONIA}

http://www.fcmedinasidonia.com/

Dentro de la página general de la Fundación Casa de Medina Sidonia, aparece un enlace al Archivo.
Tras una breve descripción general de los fondos del Archivo, se accede a un indice cronológico detallado de la documentación que contiene, con información de los orígenes de los distintos fondos procedentes de diversas casas aristocráticas y de la configuración de archivo. Asimismo, incluye una galería de fotos.

\section{MUSEO ARQUEOLÓGICO JEREZ DE LA FRONTERA}

http://www.museoarqueologico webjerez.com/

Contiene amplia información relativa a la creación y los fines del Museo, las instalaciones que ocupa y su entorno o los fondos del museo, procedentes de yacimientos arqueológicos de Jerez. Asimismo, cuenta con secciones dedicadas a información general y servicios que se prestan, a enlaces de interés o a otros aspectos relacionados con el ámbito temático del museo. 


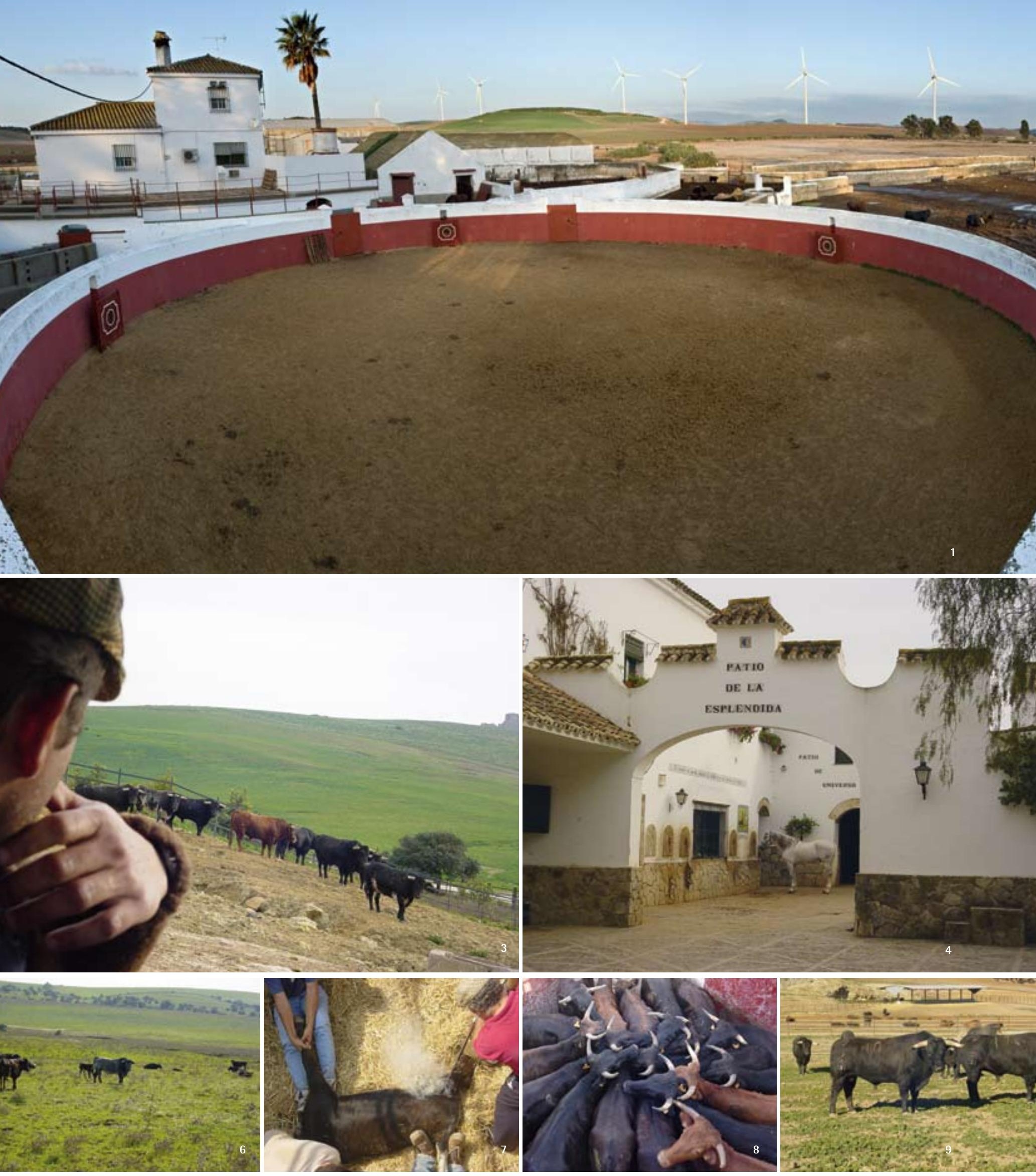

La crianza, cuidado y selección del toro bravo de lidia es un ritual

perfectamente instaurado en las fincas ganaderas, desde la herradura de la

res y la selección de los erales machos más bravos en los tentaderos hasta

el cuidado en la dehesa de los ejemplares seleccionados para la lidia.

Fotos: Manuel Sotelino, excepto 1 y 5 realizadas por Juan Carlos Cazalla,

$\mathrm{APH}$ 

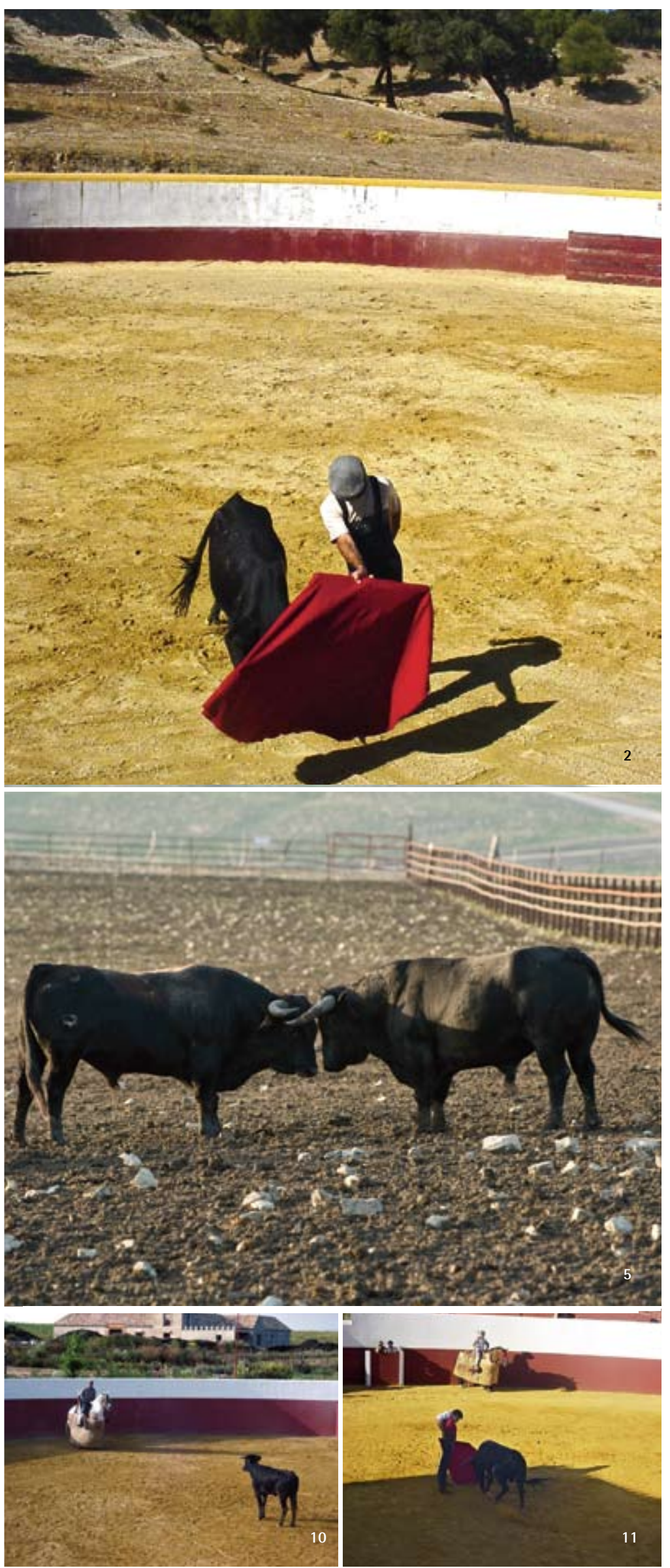

11
Siglos de manejo, cuido, selección y estudios del carácter de este auténtico rey de nuestra dehesa lo han convertido en un patrimonio sentimental a destacar, un patrimonio natural que se mantiene hasta nuestros dias, un activo unido a nuestra cultura, a nuestras costumbres y a nuestros valores más atávicos

Una vez herradas todas las reses que tienen poco menos de un año, los machos son separados de las hembras. Ellos van a ser cuidados minuciosamente para ser lidiados mientras que las hembras irán destinadas a la selección antes dicha del tentadero con el objeto de madrear aquellas que sean aptas según los criterios del ganadero.

La dehesa se abre desde ese momento al toro para que gobierne las tierras a sus anchas. Las vacas estarán durante toda su vida dando sus frutos, acompañadas del semental cuando llegue el momento de la cubrición. Por el contrario, los machos con menos hechuras irán destinados a becerradas, capeas y festivales, quedándose para cuatreños los más bonitos de lámina.

Tan sólo quedarán pendientes faenas de control sanitario, para cumplir con todos los requerimientos necesarios de salubridad de las reses, y los apartados cuando los toros lleguen a utreros. Unos irán a plazas de primera categoria por su porte engallado y sus buidos pitones. Otros, por tener menos cara, serán lidiados en plazas de menor exigencia. Los mayorales, acompañados de sus vaqueros, estarán pendientes de la alimentación de las reses que, en tiempos de calor y menos pastos, se reforzará con piensos totalmente naturales, enriquecidos con habas, glucosas y algarrobas.

Conforme vayan pasando los meses y el toro vaya haciéndose adulto, irán a los cerrados más cercanos al cortijo, toda vez que los malos humos van subiendo y las pueriles peleas de novillos suelen ir a mayores, causando bajas muy importantes para la programación de la temporada. Con la noche, el mugido o el reburdeo del toro romperán la oscuridad del cielo. Los vientos de levante los harán más hoscos al no ver cerca apriscos donde guarecerse del molesto viento y de la tierra que se levanta. Se creen auténticos poseedores de la naturaleza. El hombre estará pendiente de que el ajuste de cuentas no llegue a mayores. Siglos de manejo, cuido, selección y estudios del carácter de este auténtico rey de nuestra dehesa lo han convertido en un patrimonio sentimental digno de destacar. Es un patrimonio natural que se mantiene hasta nuestros dias, un activo unido a nuestra cultura, a nuestras costumbres y a nuestros valores más atávicos. 


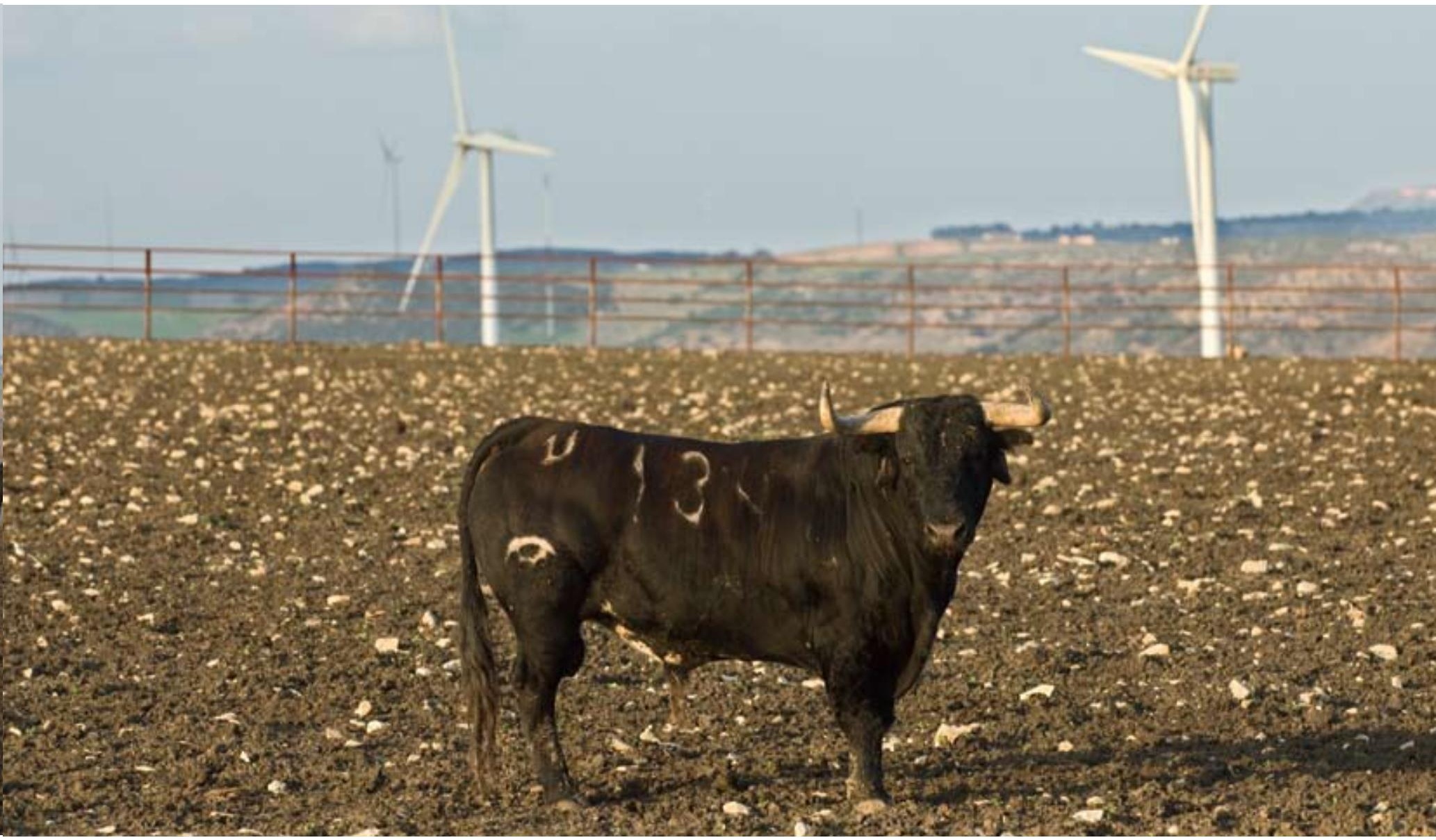

las reses que cuida. Este emplazamiento es la plaza de tientas. Es el lugar donde el ganadero, ayudado por el conocedor, selecciona aquellas hembras que mejor comportamiento han tenido en la tienta, y que se fundamenta en la acometividad de la res en el caballo y en la forma de embestir a los engaños. Rebosarse con clase yendo a coger los flecos de la pañosa con bravura, fuerza y codicia. Las camadas de eralas pasan todas por la plaza de tientas. Los machos son seleccionados para ser tentados tras vérseles hechuras y reata, es decir, estudiando los libros genealógicos y eligiendo aquellos erales o utreros que, por familia, merecen ser vistos para ser futuros progenitores si salvan la dura prueba de la tienta. Éstos pasarán en principio a ser sementales de prueba, se les observarán las crías que ha dado dos años más tarde $y$, si los objetivos están cumplidos al dar descendencia brava, pasarán a ser sementales contrastados.

Las demás faenas de campo están encaminadas al mejor cuido de las reses que pastan en la finca. A los diez meses, más o menos, llega el herradero, que es la faena de campo donde se marca e identifica con un número las cabezas de ganado que van a ser destetadas de sus madres. Es una faena que siempre ha ido acompañada de un cierto tono de fiesta, acabándose siempre la labor con un buen cocido campero mientras las crias berrean echando de menos las ubres de sus madres.

\section{En la web}

\section{AULA DE INVESTIGACIÓN HISTÓRICA GERIÓN}

http://www.gerionsanlucar.com/

Web de la Asociación cultural para la investigación y fomento de la historia y el arte y la defensa del Patrimonio Histórico de Sanlúcar de Barrameda. Además de ofrecer información general sobre la asociación, sus origenes y funcionamiento, cuenta con una sección para publicar artículos de opinión enviados por los interesados y otra para noticias. También incluye un blog para participar en debates sobre diversos temas y otra página de enlaces.

\section{ARCHIVO DE LA FUNDACIÓN CASA MEDINA SIDONIA}

http://www.fcmedinasidonia.com/

Dentro de la página general de la Fundación Casa de Medina Sidonia, aparece un enlace al Archivo.
Tras una breve descripción general de los fondos del Archivo, se accede a un indice cronológico detallado de la documentación que contiene, con información de los orígenes de los distintos fondos procedentes de diversas casas aristocráticas y de la configuración de archivo. Asimismo, incluye una galería de fotos.

\section{MUSEO ARQUEOLÓGICO JEREZ DE LA FRONTERA}

http://www.museoarqueologico webjerez.com/

Contiene amplia información relativa a la creación y los fines del Museo, las instalaciones que ocupa y su entorno o los fondos del museo, procedentes de yacimientos arqueológicos de Jerez. Asimismo, cuenta con secciones dedicadas a información general y servicios que se prestan, a enlaces de interés o a otros aspectos relacionados con el ámbito temático del museo. 


\section{Mostos y Tabancos. Espacios de sociabilidad en la cultura tradicional jerezana}

Pilar Zafra Costán, Centro de Documentación del IAPH

Sabor a tierra y tradición, olor a raíces, a tierra labrada, a entronques, a viejos palos que se celebran, se actualizan en cada trago, en cada encuentro, con cada pique, en cada arranque... Banderas rojas ondean al pie de los caminos de las casas de viña que jalonan los viñedos de la campiña jerezana, se perfilan sobre el fondo verde del dintel de los viejos tabancos que aún perviven en el entramado de la ciudad donde se bailaba "el jaleo de Jerez". El nuevo mosto da pie a una vida social intensa bien adentrado el otoño y en las puertas del invierno; su llegada se celebra como arcaico festejo que amaina los primeros fríos.

Encajado entre el mar y la montaña, entre las vegas del río Guadalete, las marismas y los pastizales, un paisaje de horizontes abiertos de albariza, modelado por la alternancia de cultivos de secano y viñedos, por la impronta de añejos modelos latifundarios, por el trabajo de braceros a tiempo... dibuja el perfil de la campiña gaditana a su paso por Jerez.

Encrucijada histórica de caminos de ida y vuelta entre Cádiz y Sevilla, Jerez de la Frontera hace del binomio vino y flamenco un dualismo mágico, una combinación que lleva a sus límites en los distintos espacios de representación que definen su entramado urbano y antropizan su paisaje.

Antes de que la riqueza y diversidad de determinados fenómenos culturales fuese difundida de forma global e incluso ensalzada convenientemente por el tópico o la reiteración por la inmensa potencia de los medios de comunicación, los rasgos esenciales de aquellas realidades culturales se tornaban más nítidos y especialmente los referidos a sus vínculos con un territorio, con el espacio concreto en los que se fraguó. Culturas como la vitivinicola y expresiones tan relevantes como el flamenco, insertas en un marco como el que perfila la campiña gaditana de Jerez, conforman un hecho cultural inexplicable fuera de los límites que establece su condición territorial, una triada que se marida a partir de una determinada condición social, económica y cultural que se ha ido vertebrando al compás del paso del tiempo, proyectándose en su fisonomia, sus específicas formas expresivas y modos de vida.

Esa estrecha relación entre la actividad productiva y las manifestaciones culturales en Jerez se torna como un fenómeno perceptible desde muy diferentes escalas. Un universo omnipresente en su condición de gran pueblo, cuya apariencia le acerca a lo urbano en la misma medida que sus actividades lo definen como rural, en las edificaciones agrarias que determinan su paisaje vitivinícola o en la importante arquitectura bodeguera que afecta directamente a su entramado. Sin embargo, es en las antiguas ventas de las afueras, en las muchas casas de viña, que con el nacimiento del nuevo mosto abren sus puertas para dispensar comida y trago, o en el devenir cotidiano de los modestos tabancos que aún sobreviven en barrios como el de Santiago o San Miguel, donde esta vinculación entre vino y flamenco ha de entenderse como parte fundamental de los rituales de convivencia.

Es en los tabancos y mostos, en estos reductos intimos de vecindad, donde vino y flamenco encuentran su eje, porque más allá de los clichés impuestos estos espacios de encuentro rezuman un trasfondo de realidad humana, de buscarse la vida, de compartirla, de cantarla. Sin más acompañamiento que las palmas, los pitos, los nudillos sobre el mostrador, el cante se alterna con la conversación, el chiste, el comentario, dentro de un elevado grado de comunicación interpersonal, transmisión, tensión y provocación emocional que suele ser aderezado con el lubricante social del vino, que ha procurado las mejores horas de convivencia y ha dado al cante su soplo orgiástico. Baste recorrer sus calles o los caminos que jalonan sus campos para percatarse de que en Jerez esto no es un hecho aislado.

Estos espacios han ser entendidos como referentes de la identidad social, preferentemente masculina, que definen experiencias, actitudes y comportamientos; como espacios, en suma, de ritualización, de interrelación, transmisión social y formación de grupo que, en el caso de los tabancos, han ido languideciendo, llegando 

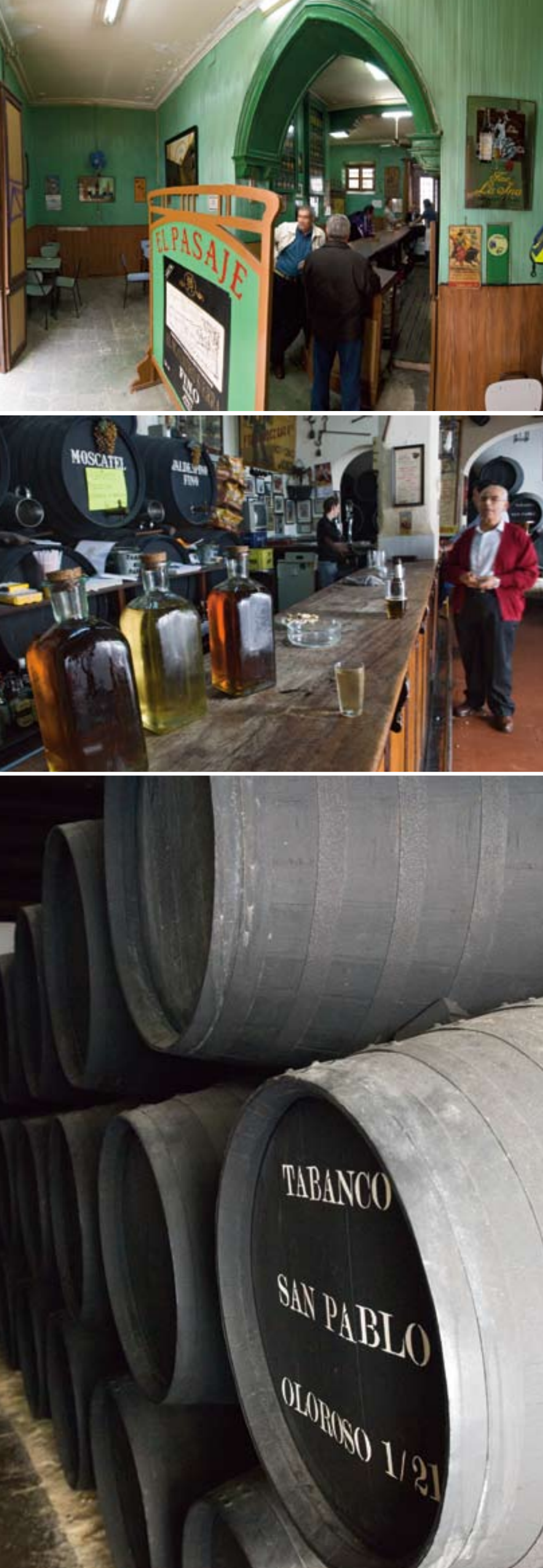

a desaparecer en su mayoría, pero que también forman parte de la historia y cultura jerezana.

Los contrastes sucesivos que infunde el trazado urbano de Jerez le confieren una fisonomía personal, complementada por la arquitectura de sus cascos de bodegas, desde los que emergen exultantes aromas de vinos para cristalizarse con el acervo cultural que destilan barrios tan representativos como los de Santiago o San Miguel, claves en la geografía del flamenco por ser cuna y cantera de cantes y grandes creadores e intérpretes de lo jondo.

Insertos en pleno corazón de estos barrios, perduran apenas algunos ejemplos testimoniales de uno de los referentes más importantes en la cultura popular jerezana, de tanta importancia en el consumo interior de vinos: los tabancos. Establecimientos tradicionales muy masculinizados que servían para vender vino en la propia ciudad y que en Jerez nada tienen que ver con la definición que reciben en los distintos diccionarios como puesto de venta ambulante o callejera, porque si algo caracteriza al tabanco es su vocación de taberna, de pequeño rincón bodeguero donde se escanciaba vino de varias botas, chicas o medianas, dispuestas en segunda o tercera.

Como el Pasaje de la calle Santa María, uno de los pocos que quedan en la ciudad, eran los tabancos jerezanos locales espaciosos. De techo alto de viguería vista y antaño de suelo terrizo cubierto de arena de canto amarillo. Tenían un amplio mostrador, tras el cual se alzaba un cachón o pequeña andana de botas. Pocas mesas y varias sillas de anea. El tabanco era un local popular donde se despachaba, para calmar la sed del parroquiano, directamente de los barriles a chorro de canilla, buen fino y vino oloroso.

Fue el templo de la iglesia parroquial de San Miguel, como el de Santiago, el punto de partida del asentamiento de familias flamencas que darian origen al popular barrio de La Plazuela. En sus cercanías aún abre sus puertas el Tabanco San Pablo, testimonio de aquellas tascas donde sólo se servía vino recio en dosis de a medio tapón y se cantaban las penas. Fueron establecimientos claves en la gestación de los mejores cantes y es de los pocos que se conservan a la antigua usanza.

Como expresión cultural, el flamenco no es un elemento único y representativo de Jerez de la Frontera; sin embargo, es posible afirmar que en esta localidad gaditana adquiere una especial significación nada azarosa. El motivo reside en que, fundamentalmente en lo ambiental y lo social, en el Jerez de antaño se hallaban unidas dos maneras de vida y trabajo: la del campo o la viña y la de la bodega. Junto a las reuniones familiares, bodas y bautizos, en los patios o en

Tabanco El Pasaje. Calles Santa María y Mesones (Jerez de la Frontera, Cádiz). Foto: Juan Carlos Cazalla, IAPH

Tabanco San Pablo, emplazado en la calle del mismo nombre (Jerez de la Frontera, Cádiz). Foto: Juan Carlos Cazalla, IAPH

Andana de botas. Tabanco San Pablo, emplazado en la calle del mismo nombre (Jerez de la Frontera, Cádiz). Foto: Juan Carlos Cazalla, IAPH 
los largos atardeceres campesinos de los almijares, el cante en Jerez hay que situarlo en ese convivir de hombres del vino, en la reunión de amigos en el tabanco del barrio al término de la tarea.

Los tabancos, que con el paso del tiempo han ido desapareciendo siendo su presencia tan sólo testimonial en la actualidad, componen verdaderos espacios de flamenco. Sin horarios ni fechas concretas, estos lugares constituian la voz de un pueblo que escenificaba cantando y bailando sentimientos, experiencias y anhelos.

Jerez se desdibuja a medida que el paisaje impone su presencia en su salida hacia Trebujena. Lo urbano da paso a un paisaje cuajado de viñedos, sobre cuyos altozanos dominan los tradicionales caserios de viña. Casi siempre encalados y de factura sobria en lo decorativo, sus blancos volúmenes se erigen sobre la zona más elevada del terreno, al objeto de obtener desde ellas una visión panorámica de sus pagos.

Dicen que "por san Andrés el mosto vino es" y es que con la llegada de los fríos invernales que anuncian el mes de diciembre muchas de aquellas casas de viña que peinan la campiña jerezana se visten de rojo indicando con banderolas al pie de cada senda que ya hay mosto en las despensas.

Es justo el tiempo en que los caminos hacia Trebujena comienzan a ser más transitados que de costumbre; el Jerez joven acaba de nacer. Mostos como el de El Domi abren sus puertas para acoger a los numerosos parroquianos que hasta la llegada de la primavera acompañarán cada trago de un buen plato de ajo campero o berza, convirtiendo la reunión en torno al mosto más en un ritual que en un simple almuerzo de domingo. Comida de jornaleros y bebida de trabajadores. Pequeñas casas de viña, como la de El Carmen, que tantos quehaceres y fatigas acogieron, han sido testigos de más afanes: albergaron la pausa del trabajo, sueños y desvelos, tratos y transacciones de todo género de la gente de campo. Con el flamenco como compañero de fatigas, han compartido risas y sudores, constituyendo un espacio ineludible de la sociabilidad jerezana. Durante los minutos de descanso de la jornada, estas fuentes de tradición daban la cara.

Hasta mediados del siglo XIX, Jerez se encontraba rodeado de viñedos que ocupaban la mayor parte de las tierras de labor junto a cereales y olivos. La plaga de filoxera provocó que parte de las vides fueran sustituidas por otros cultivos que vinieron a enriquecer el horizonte de la campiña de Jerez. Sin embargo, la significación patrimonial y cultural que introduce este paisaje revela la histórica relación de los jerezanos con su territorio. La

Viña El Carmen (Jerez de la Frontera, Cádiz). Foto: Juan Carlos Cazalla, IAPH Paisaje de viñedos (Jerez de la Frontera, Cádiz). Foto: Juan Carlos Cazalla, IAPH
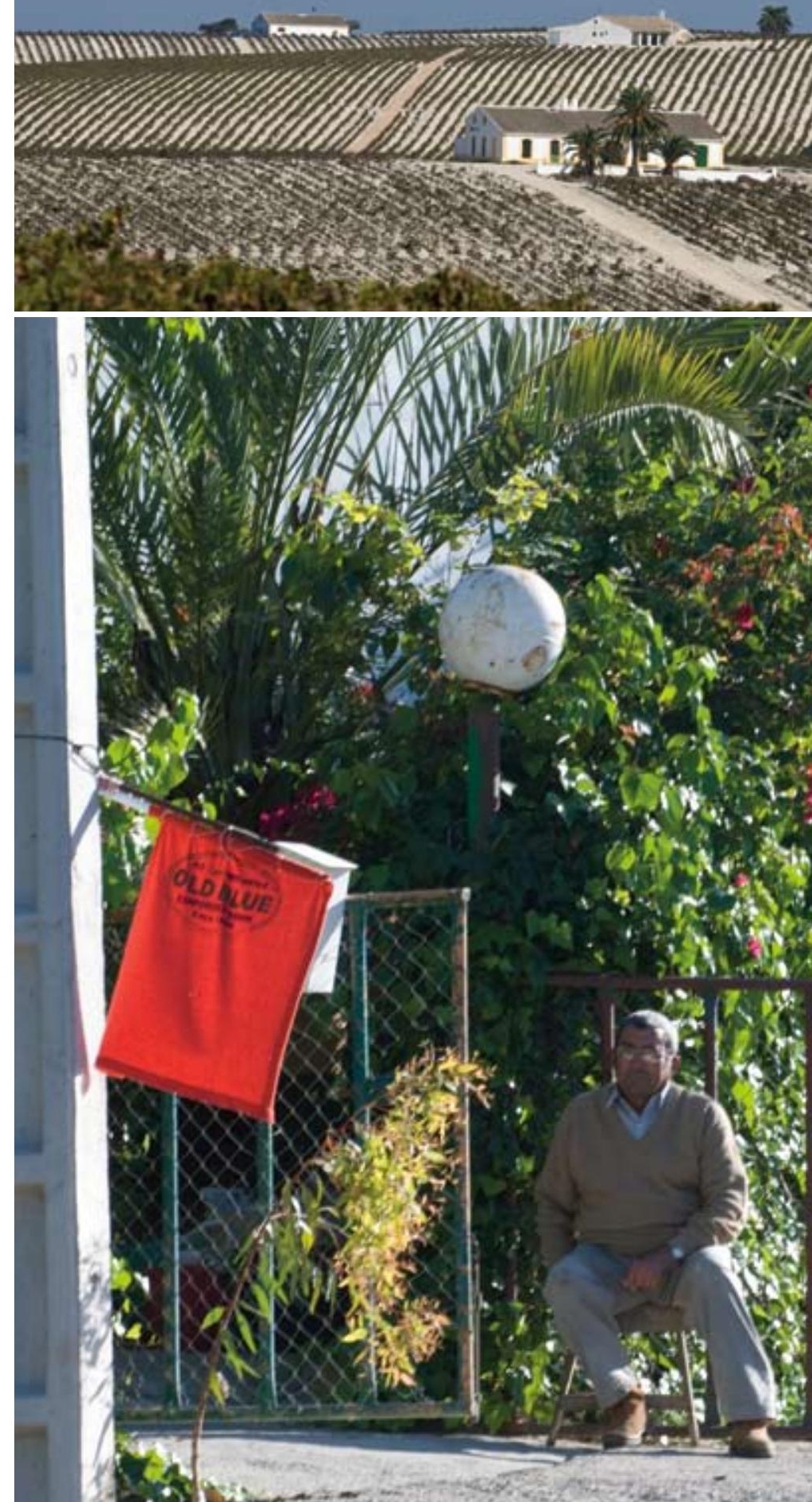

cultura del vino ha sido sin duda un elemento fundamental del tejido cultural jerezano, popular tanto por su consumo como por su presencia física, económica y olfativa. Pero no sólo el viñedo fragua el terreno, sino también las edificaciones agrarias vinculadas con este sistema de aprovechamiento, que contemplan el espacio construido hasta hacerlo lugar de vida. Casas de viña como San Cayetano, probablemente de mediados del siglo XIX, definen la arquitectura caracteristica del viñedo de Jerez. Una estructura rectangular, de factura simple de cubierta a dos aguas de teja árabe, que apoya a modo de faldón sobre un pórtico adintelado de gran plasticidad, revela la distribución habitual de estas construcciones: desde el zaguán, que cerraba la explanada del almijar, se accedia a la vivienda del propietario, a la cuadra y al lagar, que permitía el paso al resto de habitaciones. Destinadas en origen a la obtención de mosto o zumo de uva y determinadas por la presencia del lagar como pieza esencial de su funcionamiento, desde hace cuarenta años a esta parte han visto tornar sus funciones, convirtiendo en venta lo que en su día constituyeron estos espacios productivos tradicionales tan singulares dentro de la campiña gaditana.

Mostos como El Corregidor Viejo, se han erigido a lo largo del tiempo en escenario rural único de relaciones humanas. No se puede echar una mirada atrás en el pasado más reciente sin tenerlos en cuenta porque no sólo son historia, son una realidad llena de vitalidad que se cotiza en el mercado de tiempo libre de los gaditanos.

Mostos y tabancos jerezanos, de carácter tremendamente popular, se han perfilado como uno de los escenarios naturales de la sociabilidad jerezana. Durante su existencia no sólo han calmado los ánimos de parroquianos y forasteros despachando vino de la tierra y viandas, sino que han albergado la vida y han visto germinar el arte. Sabia de gitaneria, de tertulias, de cante y baile, pueden haber despachado insomnios pero han generado sueños prodigados al amor de la candela de inmensas chimeneas y de un tablao.

\section{Bibliografía}

ALADRO PRIETO, José Manuel. Algunas claves para la comprensión del paisaje rural del viñedo del marco de Jerez. Revista de historia y teoría de la arquitectu$r a, n^{\circ} 2-3,2002$, p. 260-273 *

ALADRO PRIETO, José Manuel. Paisaje, Memoria y Patrimonio, claves para el entendimiento patrimonial del paisaje vitícola jerezano. En: I Congreso Internacional "Patrimonio, Desarrollo Rural y Turismo en el Siglo XXI" (Osuna, 20-22 octubre 2004). Sevilla : Universidad de Sevilla, 2004, p. 21-31

ARCHIVO MUNICIPAL DE MEDINA SIDONIA. Inventario del Archivo Municipal de Medina Sidonia / Victoria Martín Mila, Francisca Ruano Fernández. Cádiz : Diputación Provincial de Cádiz, 1992

ASOCIACIÓN INTERNACIONAL DE HISTORIA Y CIVILIZACIÓN DE LA VID Y EL VINO. SIMPOSIO (1. 1999. El Puerto de Santa Maria). Actas del I Simposio de la Asociación Internacional de Historia y Civilización de la Vid y el Vino / Javier Maldonado Rosso (ed.). El Puerto de Santa María : Asociación Internacional de Historia y Civilización de la Vid y el Vino : Ayuntamiento de El Puerto de Santa María, 2001, 2 v. *

CORTIJOS, haciendas y lagares : arquitectura de las grandes explotaciones agrarias de Andalucía : provincia de Cádiz. [Sevilla] : Consejería de Obras Públicas y Transportes, Dirección General de Arquitectura y Vivienda, 2002 * cossío, José María de; DíAZ CAÑABATE, Antonio. Los toros : tratado técnico e histórico. Madrid : Espasa Calpe, 1943-1997

DELGADO POULLET, José. Casas de viña de El Puerto y Jerez. En: Actas de las VI Jornadas del vino fino. El Puerto de Santa María : Ayuntamiento, D.L. 2001

DURÁN SALADO, Maria Isabel. La otra banda : Sanlúcar de Barrameda en la territorialización de Doñana : siglos XIV-XX. [Sevilla] : Junta de Andalucía, Consejería de Cultura, D.L. 2003 *

ESPAÑOL ECHÁNIZ, Ignacio. Carretera y paisaje : recomendaciones para la gestión y mejora del paisaje de la carretera. Madrid: Ministerio de Fomento, 2008

GÓMEZ DİAZ, Ana María. La manzanilla : historia y cultura, las bodegas de Sanlúcar. Sanlúcar de Barrameda : Pequeñas Ideas Editoriales, [2002]

IGLESIAS RODRÍGUEZ, Juan José (ed.). Historia y cultura del vino en Andalucía. Sevilla : Universidad de Sevilla, Secretariado de Publicaciones, 1995 *

MALDONADO ROSSO, Javier...[et al.]. Añadas y soleras : catálogo de la exposición sobre los vinos, vinagres, aguardientes y licores de la provincia de Cádiz = Añadas \&t soleras : catalogue for the exhibition about wines, vinegars, spirits and liquors in Cádiz district. Cádiz : Diputación de Cádiz, 1997 *
MALDONADO ROSSO, Javier [et al.]. Manual Patrivit para la localización y catalogación del patrimonio vitícola mueble e histórico. El Puerto de Santa María : Ayuntamiento de El Puerto de Santa María, Area de Fomento, $1997^{*}$

MARCOS ARÉVALO, Javier (ed.). Las culturas del vino : del cultivo y la producción a la sociabilidad en el beber. Sevilla : Signatura, 2005 *

MUSEO ARQUEOLÓGICO MUNICIPAL DE JEREZ DE LA FRONTERA. Museo Arqueológico Municipal [de] Jerez de la Frontera. Jerez: Servicio de Publicaciones del Ayuntamiento, D.L.1997*

PLATA, Juan de la. Los tabancos y ventas de Jerez : antiguas tiendas de montañeses, grandes cafés y viejos bares, cervecerías, cabarets y salones de baile. Jerez de la Frontera : Ediciones Cofrán, D.L. 2003

SOTELINO, Manuel. Cádiz Bravo : un recorrido por las ganaderías y las familias ganaderas del toro bravo en Cádiz. Jerez : Publicaciones del Sur, 2004

Nota: Bibliografia resumida de la sección. Para una mayor información puede dirigirse a la Biblioteca del IAPH. Las publicaciones marcadas con asterisco ${ }^{*}$ ) se encuentran disponibles para su consulta en la Biblioteca del IAPH. 
cultura del vino ha sido sin duda un elemento fundamental del tejido cultural jerezano, popular tanto por su consumo como por su presencia física, económica y olfativa. Pero no sólo el viñedo fragua el terreno, sino también las edificaciones agrarias vinculadas con este sistema de aprovechamiento, que contemplan el espacio construido hasta hacerlo lugar de vida. Casas de viña como San Cayetano, probablemente de mediados del siglo XIX, definen la arquitectura caracteristica del viñedo de Jerez. Una estructura rectangular, de factura simple de cubierta a dos aguas de teja árabe, que apoya a modo de faldón sobre un pórtico adintelado de gran plasticidad, revela la distribución habitual de estas construcciones: desde el zaguán, que cerraba la explanada del almijar, se accedia a la vivienda del propietario, a la cuadra y al lagar, que permitía el paso al resto de habitaciones. Destinadas en origen a la obtención de mosto o zumo de uva y determinadas por la presencia del lagar como pieza esencial de su funcionamiento, desde hace cuarenta años a esta parte han visto tornar sus funciones, convirtiendo en venta lo que en su día constituyeron estos espacios productivos tradicionales tan singulares dentro de la campiña gaditana.

Mostos como El Corregidor Viejo, se han erigido a lo largo del tiempo en escenario rural único de relaciones humanas. No se puede echar una mirada atrás en el pasado más reciente sin tenerlos en cuenta porque no sólo son historia, son una realidad llena de vitalidad que se cotiza en el mercado de tiempo libre de los gaditanos.

Mostos y tabancos jerezanos, de carácter tremendamente popular, se han perfilado como uno de los escenarios naturales de la sociabilidad jerezana. Durante su existencia no sólo han calmado los ánimos de parroquianos y forasteros despachando vino de la tierra y viandas, sino que han albergado la vida y han visto germinar el arte. Sabia de gitaneria, de tertulias, de cante y baile, pueden haber despachado insomnios pero han generado sueños prodigados al amor de la candela de inmensas chimeneas y de un tablao.

\section{Bibliografía}

ALADRO PRIETO, José Manuel. Algunas claves para la comprensión del paisaje rural del viñedo del marco de Jerez. Revista de historia y teoría de la arquitectu$r a, n^{\circ} 2-3,2002$, p. 260-273 *

ALADRO PRIETO, José Manuel. Paisaje, Memoria y Patrimonio, claves para el entendimiento patrimonial del paisaje vitícola jerezano. En: I Congreso Internacional "Patrimonio, Desarrollo Rural y Turismo en el Siglo XXI" (Osuna, 20-22 octubre 2004). Sevilla : Universidad de Sevilla, 2004, p. 21-31

ARCHIVO MUNICIPAL DE MEDINA SIDONIA. Inventario del Archivo Municipal de Medina Sidonia / Victoria Martín Mila, Francisca Ruano Fernández. Cádiz : Diputación Provincial de Cádiz, 1992

ASOCIACIÓN INTERNACIONAL DE HISTORIA Y CIVILIZACIÓN DE LA VID Y EL VINO. SIMPOSIO (1. 1999. El Puerto de Santa Maria). Actas del I Simposio de la Asociación Internacional de Historia y Civilización de la Vid y el Vino / Javier Maldonado Rosso (ed.). El Puerto de Santa María : Asociación Internacional de Historia y Civilización de la Vid y el Vino : Ayuntamiento de El Puerto de Santa María, 2001, 2 v. *

CORTIJOS, haciendas y lagares : arquitectura de las grandes explotaciones agrarias de Andalucía : provincia de Cádiz. [Sevilla] : Consejería de Obras Públicas y Transportes, Dirección General de Arquitectura y Vivienda, 2002 * cossío, José María de; DíAZ CAÑABATE, Antonio. Los toros : tratado técnico e histórico. Madrid : Espasa Calpe, 1943-1997

DELGADO POULLET, José. Casas de viña de El Puerto y Jerez. En: Actas de las VI Jornadas del vino fino. El Puerto de Santa María : Ayuntamiento, D.L. 2001

DURÁN SALADO, Maria Isabel. La otra banda : Sanlúcar de Barrameda en la territorialización de Doñana : siglos XIV-XX. [Sevilla] : Junta de Andalucía, Consejería de Cultura, D.L. 2003 *

ESPAÑOL ECHÁNIZ, Ignacio. Carretera y paisaje : recomendaciones para la gestión y mejora del paisaje de la carretera. Madrid: Ministerio de Fomento, 2008

GÓMEZ DİAZ, Ana María. La manzanilla : historia y cultura, las bodegas de Sanlúcar. Sanlúcar de Barrameda : Pequeñas Ideas Editoriales, [2002]

IGLESIAS RODRÍGUEZ, Juan José (ed.). Historia y cultura del vino en Andalucía. Sevilla : Universidad de Sevilla, Secretariado de Publicaciones, 1995 *

MALDONADO ROSSO, Javier...[et al.]. Añadas y soleras : catálogo de la exposición sobre los vinos, vinagres, aguardientes y licores de la provincia de Cádiz = Añadas \&t soleras : catalogue for the exhibition about wines, vinegars, spirits and liquors in Cádiz district. Cádiz : Diputación de Cádiz, 1997 *
MALDONADO ROSSO, Javier [et al.]. Manual Patrivit para la localización y catalogación del patrimonio vitícola mueble e histórico. El Puerto de Santa María : Ayuntamiento de El Puerto de Santa María, Area de Fomento, $1997^{*}$

MARCOS ARÉVALO, Javier (ed.). Las culturas del vino : del cultivo y la producción a la sociabilidad en el beber. Sevilla : Signatura, 2005 *

MUSEO ARQUEOLÓGICO MUNICIPAL DE JEREZ DE LA FRONTERA. Museo Arqueológico Municipal [de] Jerez de la Frontera. Jerez: Servicio de Publicaciones del Ayuntamiento, D.L.1997*

PLATA, Juan de la. Los tabancos y ventas de Jerez : antiguas tiendas de montañeses, grandes cafés y viejos bares, cervecerías, cabarets y salones de baile. Jerez de la Frontera : Ediciones Cofrán, D.L. 2003

SOTELINO, Manuel. Cádiz Bravo : un recorrido por las ganaderías y las familias ganaderas del toro bravo en Cádiz. Jerez : Publicaciones del Sur, 2004

Nota: Bibliografia resumida de la sección. Para una mayor información puede dirigirse a la Biblioteca del IAPH. Las publicaciones marcadas con asterisco ${ }^{*}$ ) se encuentran disponibles para su consulta en la Biblioteca del IAPH. 


\section{El Museo Arqueológico de Jerez de la Frontera}

El Museo Arqueológico Municipal de Jerez de la Frontera constituye uno de los museos locales pioneros de Andalucia, remontando sus orígenes a finales del siglo XIX. Concretamente es en el año 1873 cuando se fundó, a instancias municipales, en la galería que da ingreso al Cabildo Viejo, el denominado "Depósito Arqueológico anexo a la Biblioteca Municipal". El objetivo que se perseguia con la creación de este Depósito era la salvaguarda de los objetos arqueológicos que por una u otra causa iban apareciendo tanto en el término municipal como en la propia ciudad y que corrian peligro de pérdida.

Un importante punto de inflexión en la historia del museo fue la incorporación a, partir de 1931, de Manuel Esteve Guerrero como director de la Biblioteca y el Archivo Municipales y por tanto de la Colección Arqueológica. Las más de cuatro décadas que este estudioso de la historia y de la arqueología jerezana estuvo al frente de la Institución, supusieron un notable incremento y enriquecimiento de los fondos - por hallazgos casuales, por donaciones o bien procedentes de excavaciones arqueológicas, como las realizadas bajo su dirección en el cercano yacimiento de Mesas de Asta. Esto derivó en que aquella primitiva colección adquiriera oficialmente, mediante Orden Ministerial de 9 de septiembre de 1963, la categoría de Museo.

Abandonada en 1982 debido a lo inadecuado y obsoleto de sus instalaciones su histórica sede de la plaza de la Asunción, el museo reabre sus puertas al público completamente renovado en una nueva ubicación en 1993, siendo inscrito en 1997 en el Registro de Museos de Andalucia, formando desde entonces parte de la Red Andaluza de Museos.

La actual sede se localiza en el corazón de la ciudad medieval, en la popular plaza del Mercado, centro del histórico barrio de San Mateo. Está constituida por un conjunto de edificaciones articuladas en torno a varios patios, siendo la más emblemática una casapatio con caracteristicas propias de la arquitectura de tránsito entre de los siglos XVIII y XIX, que además tiene en su historial el haber visto nacer dentro de sus muros el primer Instituto de Enseñanza Media de la provincia de Cádiz.

Tras doce años de actividad en la nueva sede, el museo se encuentra en este momento inmerso en obras de reforma y ampliación, lo que ha obligado a su cierre temporal al público. Estas obras, promovidas por el propio Ayuntamiento, han tenido como objetivo cubrir una serie de necesidades que en unos casos se venían arrastrando desde el proyecto de 1992 y en otros han ido surgiendo en el transcurso de estos años.

Siguiendo el programa elaborado por los propios técnicos del Centro, las actuaciones se han ordenado en dos grupos: por una parte mejora de los edificios existentes y por otra obras de ampliación de nueva planta.
La zona de ampliación se desarrolla hacia la parte trasera del conjunto, en un solar anexo que, al menos desde mediados del siglo XIX, estuvo destinado a patio. En este área han sido construidos dos nuevos edificios comunicados con los anteriores. Uno de ellos se ha destinado integralmente a zona de almacenes, solucionando de esta manera un problema de espacio de depósito de fondos acuciante y muy generalizado en los museos arqueológicos, mientras que el otro ha permitido ampliar de manera notable el área expositiva.

De esta forma se ha conseguido que hoy el museo ocupe la práctica totalidad de la manzana urbana, con una superficie útil en torno a los 3200 m2, lo que supone un incremento de unos $1200 \mathrm{~m} 2$ respecto a las instalaciones anteriores. Asimismo ha aumentado en más de un tercio el espacio destinado a exposición permanente. Esto va ha permitir incorporar al recorrido materiales procedentes de las intervenciones arqueológicas que se han desarrollado en la última década en la ciudad -bienes que se encuentran en el museo en calidad de depósito de la administración autonómica-, así como adecuar el discurso expositivo a los últimos avances de la investigación.

Una vez que se proceda a su reapertura, el visitante podrá realizar un recorrido por la historia de Jerez a través de tres grandes bloques temáticos. Son las áreas correspondientes a época medieval y posmedieval las más novedosas y las que se están viendo más afectadas por las reformas en curso, al coincidir con los periodos sobre los que han tenido mayor incidencia los trabajos arqueológicos de los últimos años.

El primer bloque -heredero en gran medida del anterior montaje museográfico- recoge, a través de piezas tan conocidas como el ídolo-cilindro calcolítico del Cerro de las Vacas, el casco griego del Guadalete (s. VII a. de C.) o la cabeza-retrato de época romano-republicana procedente de Hasta Regia, lo que ha sido la evolución de los asentamientos humanos en la comarca de Jerez desde las primeras comunidades de cazadores-recolectores hasta inicios del medievo.

El segundo bloque se dedica integramente a Madinat Sharish, es decir, al nacimiento y formación de la ciudad de Jerez y a su consolidación en época almohade. Ocupa una gran sala de nueva creación, en la que la primera parte se ha destinado a los orígenes prealmohades. Sin duda serán los materiales califales procedentes en su mayoria de las recientes excavaciones realizadas en la plaza Belén -donde la pieza más emblemática es un plato en verde manganeso decorado con la figura de un hermoso ciervo de perfil, en la linea de las producciones de Madinat al Zahra- una de las estrellas de las nuevas zonas de ampliación.

En lo que se refiere a la medina almohade, además de abordar aspectos relativos a las necrópolis, cuya identificación solo ha sido posible a través de los últimos trabajos realizados, se contempla la recreación de un tramo de la muralla, con su sistema constructi- vo, una calle y una vivienda, en la que los materiales van distribuidos según funcionalidad en las distintas estancias domésticas, todo ello complementado con recursos expositivos de distinto tipo entre los que no faltan algunas reconstrucciones virtuales.

La última parte del recorrido versa sobre el desarrollo de Jerez -Xeres de la Frontera- desde su incorporación a la Corona de Castilla en 1264 hasta fines del siglo XVIII. Entre el variado elenco de bienes que componen esta sección y que se expondrán por vez primera, se encuentra un relieve inglés del siglo XV en alabastro, representando la resurrección de Cristo, del antiguo hospital de la Sangr, o un singular y casi único conjunto de recipientes de vidrio de la misma cronología, procedentes de la calle Manuel María González, que han tenido que someterse para su exposición a un complicado proceso de restauración.

Al margen de estos bloques que se distribuyen a lo largo de las once salas que tiene en la actualidad el museo, la nueva conformación a nivel arquitectónico de patios y galerías, ha permitido planificar la exposición de una manera adecuada de la colección epigráfica y heráldica. Por otra parte la conservación in situ de restos arqueológicos hallados con motivo de las obras de ampliación, muestra la secuencia arqueológica más frecuentemente documentada en las intervenciones realizadas en la ciudad y sirve de arranque para tratar aspectos relativos a metodología de trabajo en arqueología.

Además de las áreas expositivas, el museo cuenta, para cumplir con las funciones que habitualmente tienen encomendadas este tipo de establecimientos, con toda otra serie de dependencias. Unas de carácter interno -como son laboratorio de restauración, almacenes de fondos, área de investigación, área administrativa-, y otras de uso externo -biblioteca especializada en temas de arqueología y patrimonio, talleres pedagógicos-, a lo que hay que añadir también una gran sala de usos múltiples, la sala Julián Cuadra, que permite el desarrollo de exposiciones temporales, congresos, conferencias, teatro, ciclos de música, etc.

Para finalizar, un papel decisivo en el acercamiento del museo a su entorno más próximo lo está jugando la Asociación de Amigos del Museo. Su programación trimestral, coordinada con la dirección del centro -a la que sus miembros dedican con ilusión muchas horas de su tiempo- intenta dar respuesta a las inquietudes y demandas de los propios socios, realiza actividades complementarias como rutas culturales, colabora con otras asociaciones promoviendo el conocimiento y la defensa del patrimonio, pero por encima de todo se trata del mejor canal de comunicación que tiene el museo con la sociedad jerezana.

Rosalia González Rodríguez

Directora del Museo Arqueológico Municipal de Jerez 